\title{
egc Superantigens Impair Monocytes/Macrophages Inducing Cell Death and Inefficient Activation
}

\section{OPEN ACCESS}

Edited by:

Francesca Granucci,

University of Milano Bicocca, Italy

Reviewed by:

Raymond Kaempfer,

Hebrew University of Jerusalem, Israel

Xiaogang Wang,

Brigham and Women's Hospital,

United States

${ }^{*}$ Correspondence:

Marisa M. Fernández

mmfernan@ffyb.uba.ar

tThese authors have contributed equally to this work

Specialty section:

This article was submitted to Molecular Innate Immunity,

a section of the journal

Frontiers in Immunology

Received: 19 July 2019 Accepted: 09 December 2019 Published: 15 January 2020

Citation:

Noli Truant S, De Marzi MC

Sarratea MB, Antonoglou MB, Meo AP, lannantuono López LV, Fernández Lynch MJ, Todone M, Malchiodi EL and Fernández MM (2020) egc Superantigens Impair Monocytes/Macrophages Inducing Cell Death and Inefficient Activation.

Front. Immunol. 10:3008.

doi: 10.3389/fimmu.2019.03008

\author{
Sofia Noli Truant ${ }^{1,2 \dagger}$, Mauricio C. De Marzi ${ }^{1,2,3,4 \dagger}$, María B. Sarratea ${ }^{1,2}$, \\ María B. Antonoglou ${ }^{1,2}$, Ana P. Meo ${ }^{5}$, Laura V. lannantuono López ${ }^{1,2}$, \\ María J. Fernández Lynch ${ }^{1,2}$, Marcos Todone ${ }^{2,3,4}$, Emilio L. Malchiodi ${ }^{1,2}$ and \\ Marisa M. Fernández ${ }^{1,2 *}$
}

${ }^{1}$ Cátedra de Inmunología, Departamento de Microbiología, Inmunología, Biotecnología y Genética, Facultad de Farmacia y Bioquímica, Universidad de Buenos Aires, Buenos Aires, Argentina, ${ }^{2}$ Instituto de Estudios de la Inmunidad Humoral "Prof. Ricardo A. Margni" (IDEHU), UBA-CONICET, Universidad de Buenos Aires, Buenos Aires, Argentina, ${ }^{3}$ Departamento de Ciencias Básicas, Universidad Nacional de Luján, Luján, Argentina, ${ }^{4}$ Instituto de Ecología y Desarrollo Sustentable (INEDES), UNLU-CONICET, Universidad Nacional de Luján, Luján, Argentina, ${ }^{5}$ Hospital Dr. J. M. Ramos Mejía, Buenos Aires, Argentina

Bacterial superantigens (SAgs) are enterotoxins that bind to MHC-II and TCR molecules, activating as much as $20 \%$ of the $T$ cell population and promoting a cytokine storm which enhances susceptibility to endotoxic shock, causing immunosuppression, and hindering the immune response against bacterial infection. Since monocytes/macrophages are one of the first cells SAgs find in infected host and considering the effect these cells have on directing the immune response, here, we investigated the effect of four non-classical SAgs of the staphylococcal egc operon, namely, SEG, SEI, SEO, and SEM on monocytic-macrophagic cells, in the absence of $T$ cells. We also analyzed the molecular targets on APCs which could mediate SAg effects. We found that egc SAgs depleted the pool of innate immune effector cells and induced an inefficient activation of monocytic-macrophagic cells, driving the immune response to an impaired proinflammatory profile, which could be mediated directly or indirectly by interactions with $\mathrm{MHC}$ class II. In addition, performing surface plasmon resonance assays, we demonstrated that non-classical SAgs bind the gp130 molecule, which is also present in the monocytic cell surface, among other cells.

Keywords: superantigens, monocytes, innate immune response, gp130, MHC-II, THP-1

\section{INTRODUCTION}

Staphylococcus aureus is one of the major pathogens responsible for human and veterinarian diseases and life-threatening infections ranging from skin and soft tissues to toxic shock syndrome (TSS) and sepsis (1-4). The last two conditions are characterized by a non-controlled release of proinflammatory cytokines which can lead to multiple organ failure and death (5).

Many virulence factors of $S$. aureus have been described; among them, staphylococcal enterotoxins (SEs) or superantigens (SAgs) are some of the most important. These toxins can promote immunosuppression in the infected host, allowing bacterial spread and further sepsis (6-8). SAgs are not circumscribed only to S. aureus; other important pathogens such us Streptococcus pyogenes produce a broad repertoire of toxins with SAg activity. Staphylococcal and streptococcal SAgs share a common tridimensional structure and display high similarity in their amino acid sequences (9). 
SAgs interact simultaneously with major histocompatibility complex class II molecules (MHC-II) on antigen-presenting cells (APC) and with the T cell receptors (TCR) on the surface of $\mathrm{T}$ cells, in a non-conventional way as unprocessed molecules. Due to these interactions, a cytokine storm is released, leading to TSS and host immunosuppression (10-15). In addition, SAgs are strongly associated with autoimmune diseases and food poisoning (16-21). Since SAgs are resistant to high temperature and enzymatic treatment and can act at very low concentrations, they were classified as category B priority agents by the CDC because of their potential use in bioterrorism and biological warfare.

Staphylococcal SAgs are described as classical (SEA to SEE and TSST-1) and non-classical enterotoxins (SEG to SEU) (2225). This division between classical and non-classical SAgs is also extended to the streptococcal pyrogenic exotoxins (SPE $\mathrm{A}-\mathrm{C}, \mathrm{F}-\mathrm{H}$, and $\mathrm{J}$ and streptococcal superantigen $\mathrm{A}$ ) and the streptococcal mitogenic exotoxin Z (SMEZ). The interaction between immunological molecular targets and classical SAgs is very well-documented (26-33). The crystallographic structures of classical SAgs in complex with the TCR and the MHC-II molecules allowed the identification of a conserved motif over the SAgs surfaces involved in the interaction. Less is known about the interaction between these receptors on the T cells or the APCs and non-classical SAgs. The crystallographic structures available, would suggest new residues over the SAg surface involved in the interaction with TCR and MHC-II molecules (34-39).

In addition, biological differences had been reported between classical and non-classical SAgs. In this regard, an important aspect is the higher stimulatory capacity that SEB and SMEZ, both classical SAgs that bind CD28 (40-44), possess over the non-classical SAgs, for which interaction with $\mathrm{CD} 28$ has not been studied yet. These classical SAgs, which also interact with B7.2 $(42,43)$ display a stimulatory capacity three orders higher compared with SEG and SEI $(27,45,46)$.

The interaction between the co-receptors CD28 and B7.2 and classical SAgs as SEB, SPEA, SMEZ, and SEA has been deeply studied $(40-44,47)$. A conserved motif among SAgs, located at beta strand 8-alpha helix 4, distant from the TCR and MCH-II binding site, would constitute the binding region with these new ligands. The interaction with these co-receptors could allow a full $\mathrm{T}$ cell activation.

The glycoprotein 130 (gp130), a signal transductor of IL-6, was also described as a new classical SAg target. Only one study reported that the staphylococcal SAg SEA could bind to gp130 on the adipocytes' surface (48). There are no other publications describing this interaction and its biological significance on cells of the immune system.

SAgs, such as other virulence factors, are encoded in mobile genetic elements located in pathogenicity islands, phages, plasmids, and transposons. The genes of non-classical SAgs, SEG, SEI, SEM, SEN, and SEO belong to the enterotoxin gene cluster, $e g c$, which is located in pathogenicity island 3 (18). At present, seven forms of the egc operon were described (49). Sometimes, strains carrying the egc operon are also bearers of the seu gene, increasing the virulence of the strain $(18,49)$; seu is harbored in the operon instead of the pseudogenes ent1 and ent2, which are present in most forms of the operon. The egc SAgs genes are described as the most prevalent SAgs genes (50-55).

The interaction between SAgs and TCR is very wellcharacterized $(29,31,38)$. Less is known about the outcome of SAg interaction with innate immune cells. Some studies have analyzed the interaction of bacterial SAgs with human monocytes enriched from peripheral blood (56), dendritic cells (DCs) (5759), and murine neutrophils (60). Since monocytes/macrophages are one of the first cells SAgs found in infected hosts and considering the effect these cells have on directing the immune response, here we investigated the effect of four SAgs of the staphylococcal egc operon: SEG, SEI, SEO, and SEM on monocytic-macrophagic cells, in the absence of $\mathrm{T}$ cells, employing THP-1 cells, a human cell line which is broadly used as a model of monocytes and macrophages (61-63). We also analyzed other molecular targets on APCs which could directly or indirectly mediate egc SAgs effects. We found that egc SAgs depleted the pool of innate immune effector cells and induced an inefficient activation of monocytic-macrophagic cells, driving the immune response to an impaired proinflammatory profile, which could be mediated directly or indirectly by interactions with MHC class II. In addition, performing surface plasmon resonance (SPR), we demonstrated that non-classical egc SAgs bind to the gp130 molecule, which is ubiquitously expressed in immune cells.

\section{MATERIALS AND METHODS}

\section{Evaluation of SAg Genes in Autochthonous Strains of $S$. aureus}

S. aureus strains were isolated from patients and characterized in the Hospital General de Agudos “J. M. Ramos Mejía." The isolates were microbiologically identified as $S$. aureus due to their ability to coagulate citrated rabbit plasma (positive coagulase) and to produce clumping factor. Additionally, routine antibiograms were performed. The strains were isolated in LB-agar and cultured in antibiotic-free Trypticase soy broth medium with $3 \%$ $\mathrm{N}-\mathrm{Z}$ amine and $1 \%$ yeast extract $(64)$ at $37^{\circ} \mathrm{C}$ with moderate agitation $(200 \mathrm{rpm})$ up to $\mathrm{DO}_{600 \mathrm{~nm}}=1$.

DNA was isolated using the Miniprep genomic DNA isolation kit (QIAGEN, GmbH-Germany), and its integrity was checked in $0.8 \%$ agarose gel. SAg genes in the clinical isolates were evaluated by polymerase chain reaction (PCR) $(45,65-67)$ using specific primers for sags. Fc30 (35) and hsp60 were used as a positive control (SP Table 1). Positive cases were repeated and amplified using a high-fidelity polymerase (Invitrogen, Thermo Fisher Scientific Inc.). The sequencing was developed by Macrogen Inc. (Korea).

\section{Sequence Analysis}

Nucleotide and amino acid sequences were analyzed using the ExPASy Protein Translate program (Swiss Institute of Bioinformatics). Alignments were performed with BLASTNCBI and ClustalW. Three subclones were analyzed to ensure that no Taq Platinum Plus (Promega)-related mutations were introduced. For construction and analysis of sequence similarities and secondary structure, ESPript software was used as described 
elsewhere (68). The sequences were deposited at the NCBI Protein Data Bank and published with the accession numbers MK947360, MK947361, MK947362, MK947363, MK947364, MK947365, and MK947366.

\section{Monospecific Mouse anti-SAg Sera}

Animals were manipulated following the ethical standards of the Universidad de Buenos Aires, Facultad de Farmacia y Bioquímica, where the work was carried out (Resolution No. 2349/18). Polyclonal antisera were obtained by immunization of Balb/c mice with $1 \mathrm{mg} / \mathrm{ml}$ of recombinant SEG, SEI, or SSA mixed with Freund's adjuvant. Boosts were administered on days 7,14 , and 28. Sera obtained on day 35 were diluted 10 -fold and tested by ELISA and immunoblotting. Antisera were enriched in the immunoglobulin fraction by saline precipitation followed by molecular exclusion purification. The enriched fraction was treated with pepsin and then the purified $\mathrm{F}(\mathrm{ab})_{2}{ }_{2}$ fragment was used in the following assays to avoid cell proliferation or activation due to the interaction of mouse Fc fragments with human Fc receptors.

\section{Reagents and Bacterial Strains}

All chemical reagents were of analytical grade and purchased from Sigma (St. Louis, MO). Restriction enzymes, Taq DNA polymerase, T4 ligase, and buffers for cloning were purchased from New England Biolabs, Inc. (Beverly, MA). Ultrapure agarose was purchased from GIBCO BRL-Life Technologies (Rockville, MD). Recombinant Human Glycoprotein 130 Fc Chimera (gp130) was purchased from R\&D (671-GP, Bio-techne, Minneapolis, MN).

Biacore chips and the amino coupling kit were purchased from General Electric Healthcare Life Science (Piscataway, NJ). Escherichia coli DH5 $\alpha$ and BL21 (DE3) strains were from Stratagene (La Jolla, CA, USA).

\section{Recombinant Expression and Purification of Superantigens}

Streptococcal SSA and staphylococcal SEI and SEG were produced and purified as previously described $(35,65)$. Briefly, proteins cloned in pET-26b were expressed in E. coli BL21 and purified by Ni-NTA affinity chromatography, followed by S200 molecular exclusion. Proteins were treated with agarosepolymyxin B (Sigma Aldrich, St. Louis, MO) to remove LPS traces. SEM and SEO were cloned and produced following the same strategy described earlier using strain 41,399.

\section{HLA-DR1 Expression and Purification}

HLA-DR1 was produced by in vitro folding from bacterial inclusion bodies as described elsewhere (69). Briefly, plasmids encoding the HLA-DR1 $\alpha$ chain (DRA*0101) and $\beta$ chain (DRB1*0101) were transformed separately into E. coli BL21 (DE3) cells (Stratagene). Bacteria were grown at $37^{\circ} \mathrm{C}$ to an absorbance of $0.6-0.7$ at $600 \mathrm{~nm}$, and then $1 \mathrm{mM}$ IPTG was added. Inclusion bodies were extensively washed and the subunits purified under denaturing and reducing conditions using an HQ50 anion exchange column (PerSeptive Biosystems). Yields of DR1 $\alpha$ and $\beta$ subunits were 16 and $20 \mathrm{mg}$ per liter of culture medium, respectively. Purified subunits were diluted dropwise with constant stirring to a final concentration of $50 \mu \mathrm{g} / \mathrm{ml}$ into a folding solution of $20 \mathrm{mM}$ Tris- $\mathrm{HCl}(\mathrm{pH} \mathrm{8.5)}$, $25 \%$ (w/v) glycerol, $0.5 \mathrm{mM}$ EDTA, $3 \mathrm{mM}$ reduced glutathione, and $0.3 \mathrm{mM}$ oxidized glutathione and kept at $4{ }^{\circ} \mathrm{C}$ for 2 days in the presence of $1 \mu \mathrm{M}$ HA 306-318 peptide (PKYVKQNTLKLAT). Recombinant HA/HLA-DR1 was purified from the folding mixture using a Mono $\mathrm{Q}$ anion exchange column (Amersham Biosciences) equilibrated with $20 \mathrm{mM}$ Tris- $\mathrm{HCl}$ ( $\mathrm{pH} 8.0$ ) and developed with a linear $\mathrm{NaCl}$ gradient. The protein eluted as a single peak at $0.15 \mathrm{M} \mathrm{NaCl}$.

\section{Purity of Recombinant Proteins and LPS Determination}

For every recombinant protein used in this work, purity was evaluated by SDS-Page (egc SAgs in SP Figure 1). In addition, the amount of remaining endotoxin was evaluated by the Pierce LAL chromogenic endotoxin quantitation Kit (Thermo Scientific) following the manufacturers' instructions. For all recombinant proteins, it was verified that $<0.1 \mathrm{EU} / \mathrm{ml}$ of endotoxin was present.

\section{Cell Culture}

The human monocytic leukemia cell line THP-1 was obtained from the American Type Culture Collection (Manassas, VA) and cultured in complete medium [RPMI-1640 (Thermo Fisher Scientific), supplemented with $10 \%$ fetal bovine serum (FBS) (Internegocios S.A., B.A., Argentina), $2 \mathrm{mM}$ glutamine, $1 \mathrm{mM}$ pyruvate, $100 \mathrm{U} / \mathrm{ml}$ penicillin, and $100 \mu \mathrm{g} / \mathrm{ml}$ streptomycin].

When appropriate, and before each assay, cells $\left(7.5 \times 10^{5}\right.$ to 10 $\times 10^{5}$ cells $/ \mathrm{ml}$ ) were treated for $72 \mathrm{~h}$ with phorbol 12 -myristate 13-acetate (PMA, Sigma Aldrich, Saint Louis, MO) $(40 \mathrm{ng} / \mathrm{ml})$ or left untreated. Before each assay, cells were counted after trypan blue staining in a Neubauer chamber; only samples with cell viability over $98 \%$ were used.

\section{Cell Proliferation Assays}

Cell inhibition assays were assessed in THP-1 cells, cultured in the presence of SAgs (from 0.001 to $10 \mu \mathrm{g} / \mathrm{ml}$ ) or medium (control) for $24-72 \mathrm{~h}$. For $48 \mathrm{~h}$ of treatment, cells were incubated for $30 \mathrm{~h}$ at $37^{\circ} \mathrm{C}$ in $5 \%(\mathrm{v} / \mathrm{v}) \mathrm{CO}_{2}$. After that, $1 \mathrm{mCi}$ of $\left[{ }^{3} \mathrm{H}\right]$ thymidine per well was added, and cells were incubated for additional $18 \mathrm{~h}$ and then harvested on glass fiber filters. The incorporation of radioactivity was measured using a liquid scintillation analyzer Tri-Carb 2810 TR (Perkin Elmer). To evaluate the specificity of our results and putative targets involved, inhibition assays were repeated with the same concentrations of SAgs, pre-incubated or not with specific $\mathrm{F}(\mathrm{ab})^{\prime}{ }_{2}$ fragments $(10 \mu \mathrm{g} / \mathrm{ml})$ and $\mathrm{DR} 1$ recombinant protein in equimolar concentration with the toxins assayed for $1 \mathrm{~h}$ at $37^{\circ} \mathrm{C}$, and then incubated with cells for $48 \mathrm{~h}$ at $0.1 \times 10^{6} \mathrm{cell} /$ well.

\section{Immunofluorescence Assays}

THP-1 cells $\left(5 \times 10^{5}\right.$ cells/well $)$ were incubated for $48 \mathrm{~h}$ with $10 \mu \mathrm{g} / \mathrm{ml}$ of each SAg or left untreated (control 1). Cells were fixed with PFA 2\% (12 min at room temperature) and washed with PBS, and then the pellet was incubated for $30 \mathrm{~min}$ with $0.25 \%$ Triton X-100 for permeabilization. Blocking was performed by incubating $20 \mathrm{~min}$ at RT with $10 \%$ BSA-PBS. 
Primary antibodies, mouse sera anti Sags, or normal mouse sera (control 2) (dilution 1/300) were incubated for $1.5 \mathrm{~h}$, then washed, and incubated with goat anti-mouse IgG conjugated with Alexa-488 (Biolegend) (dilution 1/1,000) for $1 \mathrm{~h}$ at RT. After final washes, the pellet was resuspended in DAPI (Sigma, St Louis, MO) $(1 \mu \mathrm{g} / \mathrm{ml})$ for $30 \mathrm{~min}$. Samples were centrifuged, and a drop was observed under a fluorescent microscope (Olympus BX51TRF).

\section{Cell Death Assays}

Cell viability was measured using the fluorescein diacetate (FDA) and propidium iodide (PI) assay, both purchased from Sigma (St. Louis, MO). FDA stain was used as a control of viability. Control and SAg-treated $(10 \mu \mathrm{g} / \mathrm{ml})$ cells were collected and washed twice in PBS before re-suspension in $1.4 \mu \mathrm{M}$ of FDA and then in $1 \mu \mathrm{g} / \mathrm{ml}$ of PI. The percentage of dead cells uptaking PI was measured by flow cytometry (Partec, Germany) and analyzed using Flowing Software (Cell Imaging Core, Turku Centre for Biotechnology).

\section{Evaluation of Apoptosis by Annexin V}

For assessment of apoptotic death, the PE-Annexin V Apoptosis Detection Kit I (BD Biosciences) was employed. Briefly, $5 \times$ $10^{5}$ THP-1 cells were seeded in a 24 -flat bottom plate and incubated with SAgs $(10 \mu \mathrm{g} / \mathrm{ml})$ or medium as a control for $48 \mathrm{~h}$. Afterwards, cells were washed and resuspended in staining buffer. After $15 \mathrm{~min}$ of incubation with Annexin V-PE and 7$\mathrm{AAD}$, samples were injected into the flow cytometer, and results were analyzed using Flowing Software.

\section{Dual Acridine Orange/Ethidium Bromide Fluorescent Staining}

To confirm the cell death rates using the PE-Annexin V Apoptosis Detection Kit I, we assessed the dual acridine orange/ethidium bromide (AO/EB) fluorescent staining, visualized under a fluorescent microscope (Olympus BX51TRF). THP-1 cells were treated with SAgs $(10 \mu \mathrm{g} / \mathrm{ml})$ for $48 \mathrm{~h}$. The pelleted cell suspension $(250 \mu \mathrm{l})$ was stained with $10 \mu \mathrm{l}$ of the dye mixture $[10 \mu \mathrm{M}$ acridine orange and $10 \mu \mathrm{M}$ ethidium bromide (Sigma)], which was prepared in PBS. Cells cultured with medium were used as a control. For THP-1/PMA-treated cells, the samples were evaluated attached to the cover glasses at the same time that the supernatants were evaluated. The morphology of 200 cells per sample was examined by fluorescent microscopy within $20 \mathrm{~min}$.

\section{LDH Assay}

Supernatants of THP-1 cells treated with SAgs for $48 \mathrm{~h}$ or left untreated were evaluated using the optimized UV method (DGKC) for lactate dehydrogenase (LDH): LDH-P (Wiener Lab.). Samples were evaluated at $340 \mathrm{~nm}$ and $37^{\circ} \mathrm{C}$ according to the manufacturer's indications.

\section{Cytokine Determinations}

Cytokines (CKs) IL-6, IL-12, IFN-x, TNF- $\alpha$, IL-17A, and IL-10 were measured by ELISA from the supernatants (SN) of THP1 cells incubated with different concentrations of SAgs (R\&D
Systems, Oxon, UK). Each experiment was repeated at least three times.

\section{Phenotypic Assay}

THP- 1 cells $\left(10^{6} / \mathrm{ml}\right)$ were incubated with $1 \mu \mathrm{g} / \mathrm{ml}$ of SEG, SEI, or SSA for $24 \mathrm{~h}$ at $37^{\circ} \mathrm{C}$ in complete medium. CD14, CD40, and CD86 expression was evaluated by flow cytometry (FACS) and compared to basal expression in THP-1 cells incubated without SAgs (control). Briefly, we analyzed the THP-1 phenotype using FITC-labeled mAbs to CD40 and CD86 and PE-labeled antibodies to CD14 (eBioscience). Stained cells were analyzed by flow cytometry. At least 20,000 events were acquired for each sample, and data analysis was performed using the WinMDI software program. Results were expressed as percentage of positive cells.

\section{Phagocytosis Assays}

THP- 1 cells $\left(10^{6} / \mathrm{ml}\right)$ were cultivated with $10^{8} \mathrm{UFC} / \mathrm{ml}$ of heatdead $S$. aureus labeled with FITC in the presence of different SAgs $(1 \mu \mathrm{g} / \mathrm{ml})$ or alone. All the assays were done in complete medium. After $1-3 \mathrm{~h}$ at $37^{\circ} \mathrm{C}, \mathrm{CO}_{2} 5 \%$ incubation, cells were washed and resuspended in PBS-Trypan Blue to analyze the phagocytosis of FITC-bacteria by flow cytometry. Results were expressed as percentage of positive cells.

\section{Surface Plasmon Resonance Assay}

SPR analysis was performed using a BIAcore T100 instrument (GE Healthcare). Gp130 protein was immobilized (2200 RU) on a CM5 chip (GE Healthcare) surface by amine coupling according to the manufacturer's instructions. Soluble SEG, SEI, SEM, and SEO were diluted in PBS, pH 7.4, with or without EDTA running buffer, and injected over chip surfaces at a flow rate of $30 \mu \mathrm{l}$ $\min ^{-1}$ for $60 \mathrm{~s}$ at $25^{\circ} \mathrm{C}$. Data were analyzed with the BIA evaluation software (GE Healthcare).

\section{Statistical Analysis}

Results were tested statistically using one-way and two-way ANOVA and Dunnett's, Bonferroni's, or Tukey's multiple comparison tests where appropriate, using commercially available software (Graph-Pad Prism, GraphPad Software, San Diego, CA, USA). Results were determined to be statistically significant when a $p<0.05$ was obtained. Images were edited using Adobe Photoshop CC software (Adobe, CA, USA).

\section{RESULTS}

\section{SAgs of the egc Operon Are the Most Prevalent SAg Genes in the Evaluated Strains}

To evaluate the prevalence of classical and non-classical staphylococcal sags in $S$. aureus isolated from adult patients of our community, we analyzed 13 strains from ambulatory patients who attended the emergency service of a public hospital in Buenos Aires (SP Table 2). All strains were microbiologically confirmed as $S$. aureus by coagulase reaction and production of clumping factor. 
We assessed the presence of 15 different sags in the bacterial genomic DNA by PCR (Table 1). Classical sags were found in $60 \%$ of the isolates, with $\sec 3$ showing the highest frequency. All strains were negative for sea and see. Within the non-classical sag genes, ser and seh were not detected in any of the analyzed strains when genomic DNA was evaluated.

The presence of the egc operon was detected in $54 \%$ of the strains. sen [previously named as sek (54)] a gene that can or cannot be present in the egc operon, showed the highest prevalence (92\%), followed by seu (62\%). A non-significant relationship was found between the severity of the infection or the strain antibiotic resistance and the presence of sags.

These results are in concordance with several reports that claimed that $80 \%$ of all S. aureus strains hold, on average, five or six SAg genes, among which the egc SAgs are the most prevalent today (50-55).

The egc operon was described for the first time by Jarraud et al. (54). At that time, three forms of the egc operon were described: egcl (harboring seg, sei, sem, sen, seo, and ent1 and ent2), egc2 (harboring seu instead of ent1 and ent2), and egc3 (containing sei, seu, sen and seg variants). Blaiotta et al. (70) described egc forms 1-7 based on the length of the egc DNA fragment and its restriction enzyme assay patterns. Here, we described a non-reported form of the egc operon lacking the seo gene, which we denominated egc8, in accordance with previous works. Additionally, we found that sen was observed no matter if any form of the cluster was present or not (92\% prevalence compared with $54 \%$ prevalence of the egc operon). Furthermore, we found the presence of a reported variant of sei, sei2 $(49,52)$.

seg was found in seven isolated strains displaying slight DNA variability with mutations in residues $6,17,30$, and 77 (Figure 1A) when compared with the consensus sequence $(18,64,71)$. These mutations allowed us to group them as A, which includes isolated strains 40,900, 41,026, 41,226, and 41,399 (accession numbers MK947360, MK947361, MK947362, and MK947364) and B, which includes strains 41,395, 41,668, and 41,674 (accession numbers MK947363, MK947365, and MK947366) (Figure 1A). The mutations in position 6 (Ile instead of Leu) and 30 (Thr instead of Met) are conservative since the biochemical nature of the amino acids did not change with respect to the consensus sequences. The mutation in residue 77 is identical to the one observed in pediatric isolates (Fc30) (35). All these residues are highly solvent-exposed, and neither the MHCII binding site nor the TCR binding surfaces were affected by the mutations, according to the elucidated structure (Figure 1B).

On the other hand, sei showed the same sequence as the consensus in the two variants of the gene previously described.

\section{SAgs Inhibit Monocyte Proliferation}

Four SAgs of the egc operon were cloned in pET-26b, successfully expressed in transformed E. coli BL21 and purified (SP Figure 1). In order to study the effect of SAgs on innate immune cells and in the absence of $\mathrm{T}$ cells, a human monocyte cell line (THP-1) was cultured for $48 \mathrm{~h}$ in the presence of the four recombinant SAgs, and proliferation by $\left[{ }^{3} \mathrm{H}\right]$-thymidine was evaluated. Since sen and seu are not always present with the egc operon, they were not included in this study. All SAgs assayed caused lower proliferation rates in relation to control (untreated cells), although different potencies in their effects were observed. Figure 2 shows a representative result for $48 \mathrm{~h}$ culture of SAg with $0.2 \times 10^{6}$ cells/well where inhibition of proliferation was observed at as low as $0.1 \mu \mathrm{g} / \mathrm{ml}$ for SEG and SEI and at $10 \mu \mathrm{g} / \mathrm{ml}$ for SEM and SEO. Similar results were obtained for different cell densities $(0.2-1.0 \times$ $10^{6}$ cells/well).

\section{All SAgs Induce Monocyte Death}

We further investigated if SAgs were only responsible for inhibition of proliferation or if they were also causing cell death. At first, we observed DNA conformation and SAgs presence in THP-1 cells by immunofluorescence assay. THP-1 cells charged with SAgs in their cytoplasm presented nuclear fragmentation,

TABLE 1 | Distribution of SAgs genes in clinically isolated Staphylococcus aureus strains.

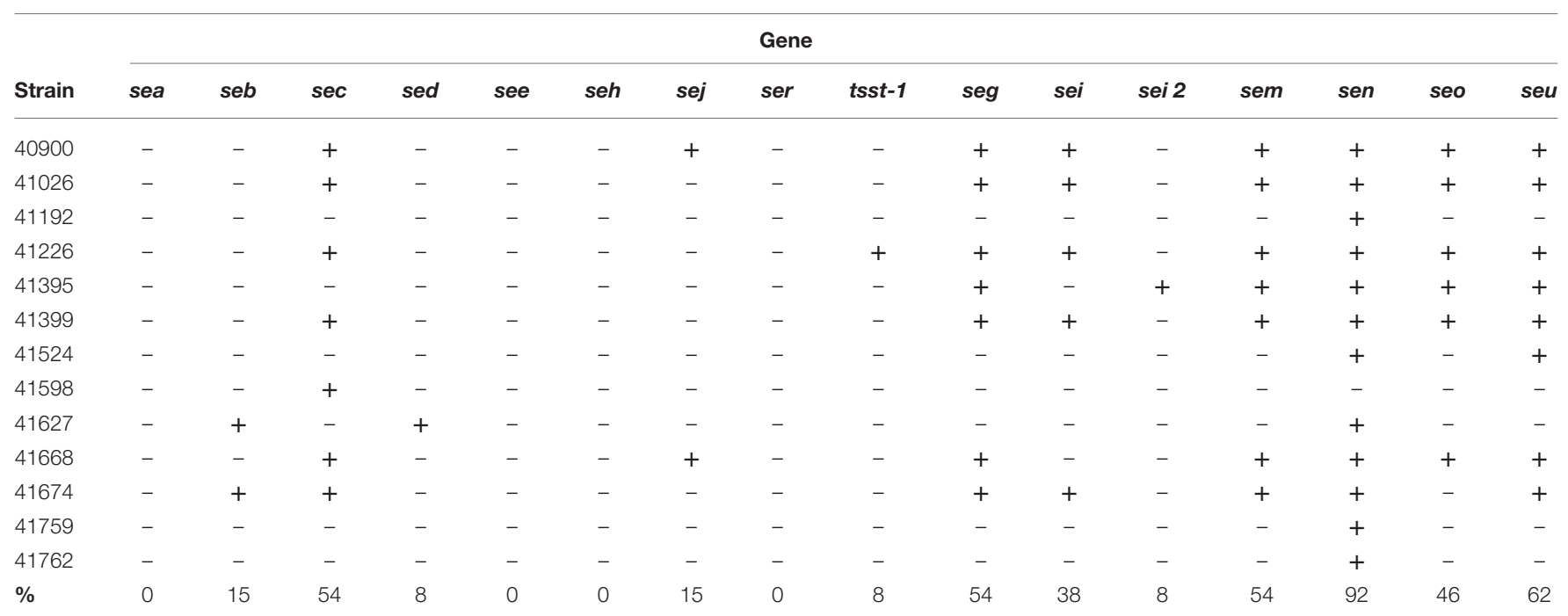




\section{A Consensus
Consensus
Group_A
Group_B
Fc30}

Consensus

Consensus

Group_A

Group_B

FC30

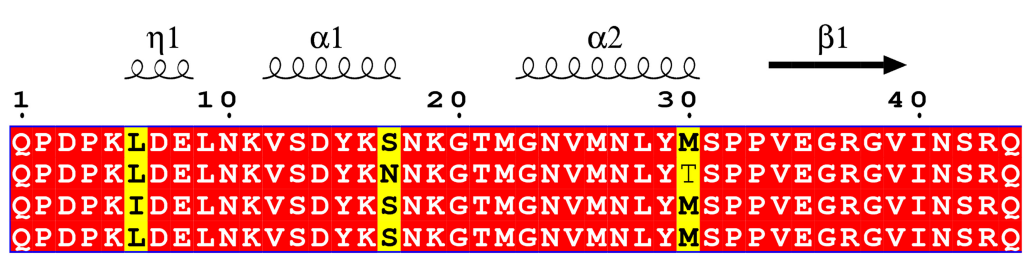

$\uparrow$

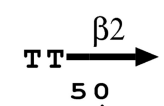

T T
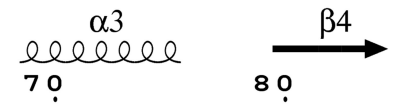

F LSHDI IFP I EYKSYNEVK TELENTELANNYK DKKVD IF GVPYF F LSHDL I F P I EYKSYNEVKTELENTELANNYKDKKVDI F GVPYF F LSHDLIFP I EYKSYNEVKTELENTELANNYKGKKVD I F GVPYF F LSHDLIFP I EYKSYNEVKTELENTELANNYKGKKVDI F GVPY

Consensus
Consensus
Group_A
Group_B
Fc30

B

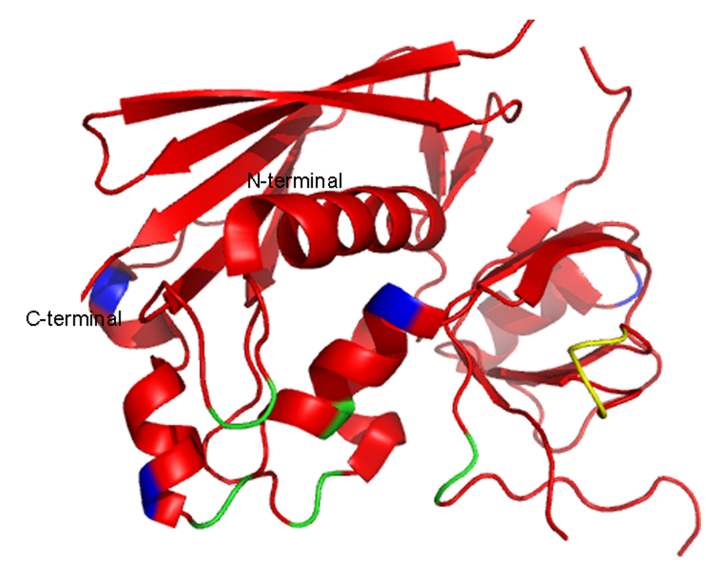

FIGURE 1 | Amino acid alignment and structure of SEG variants. (A) SEG sequence labeled as consensus has been reported in four strains (N315, Q8RR77, Mu50, and FRI572) (18, 64, 71). Group A includes strains 40900, 41026, 41226, and 41399. Group B includes strains 41395, 41668, and 41664. Fc30 is used as reference for pediatric isolates as reported by (45). Identical residues are shown in red. Arrows show sequence sites containing mutations. Sites where a unique sequence is mutated are shown in yellow, and mutated amino acids in two sequences are shown in white. (B) Overall structure of SEG (pdb 1XXG). Mutations are colored in blue, MHC-II binding site in yellow, and TCR binding site in green.

indicating cell death. Untreated cells were used as a biological control (control 1) and SAgs-treated cells incubated with normal murine sera were used to confirm assay specificity (control 2) (Figure 3A). In addition, an increment in cellular complexity was observed by flow cytometry (Figure 3B). This phenomenon was observed for all egc SAgs, suggesting intracellular events that could be related to the cell death described above.
Moreover, when THP- 1 cells were cultured in the presence of $10 \mu \mathrm{g} / \mathrm{ml}$ of SAgs for $48 \mathrm{~h}$, all toxins showed an increased percentage of PI-positive THP-1 cells, indicating cell death induction (Figure 3C).

We observed that SEG was the toxin inducing more changes in cellular complexity and an increase in cell death by PI. Moreover, SEM induced the lowest effects in both evaluated situations. 


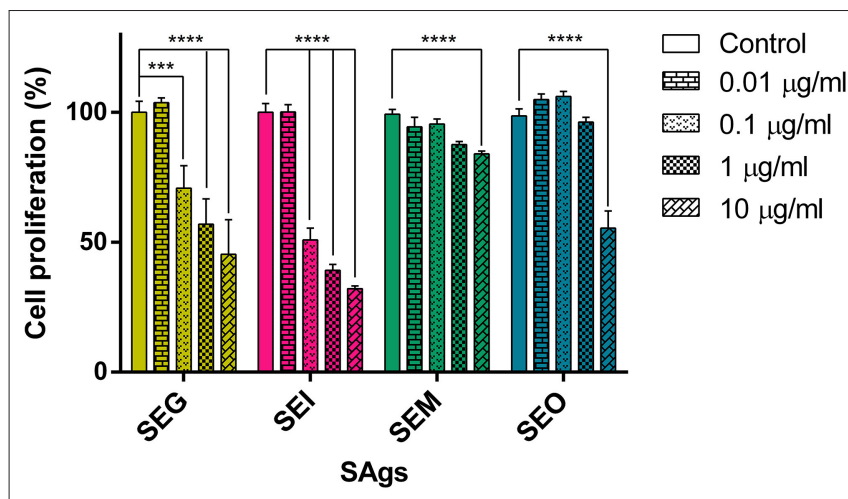

FIGURE 2 | SAgs inhibit proliferation of THP-1 cells. THP-1 cells were incubated with Sags, and proliferation by $\left[{ }^{3} \mathrm{H}\right]$-thymidine was evaluated at $48 \mathrm{~h}$. Results are expressed as the percentage of proliferation related to untreated conditions. Data are expressed as the mean \pm SEM of at least three independent experiments. Asterisks represent statistical significance with respect to untreated cells: ${ }^{\star \star \star} p<0.001,{ }^{\star \star \star \star} p<0.0001$.

PI-positive cells are usually considered as necrotic cells, but primary necrotic and post-apoptotic secondary necrotic cells could not be discriminated by this method (72). To clarify this point, we performed Annexin V/7AAD and dual acridine orange/ethidium bromide fluorescent staining. When THP-1 cells were cultured in the presence of $10 \mu \mathrm{g} / \mathrm{ml}$ of SAgs for $48 \mathrm{~h}$, all toxins increased the percentage of 7AAD positive THP-1 cells (Figure 4A). All SAgs, but SEM, increased the proportion of cells labeled with Annexin-V (Figure 4B); however, only SEI interestingly showed a low percentage of early apoptosis (Figure 4C).

Furthermore, THP-1 cells treated with SAgs followed by $\mathrm{AO} / \mathrm{EtBr}$ staining showed a viability reduction of the monocytic cells treated with the four SAgs (Figures 5A,B). SEI and SEO showed the highest increment in apoptotic cell death, compared with SEG and SEM. In contrast, although all SAgs showed an increase of cells undergoing necrosis; only SEO increase was significantly higher compared to control. In correspondence with that, only SEO increased the level of LDH measured in THP-1 supernatants (Figure 5C).

Thus, we corroborated the induction of cell death generated by these toxins, causing the depletion of effector cells from the innate immune response by multiple mechanisms. While the four toxins induced late apoptosis at $48 \mathrm{~h}$, we observed induction of early apoptosis by SEI and necrosis increment by SEO.

\section{SAgs Induce a Pro-inflammatory Cytokine Profile in Monocytes}

When supernatants of THP-1 cells cultured in the presence of SAgs for $48 \mathrm{~h}$ were analyzed, we observed a significantly higher production of cytokines IL-6, IL-12, and TNF- $\alpha$ (Figure 6). These interleukins propitiate a highly inflammatory environment, proper to eradicate an intracellular bacterium, while $S$. aureus spends most of the time as an extracellular pathogen. On the contrary, no trace of IL-17A, IFN- $\gamma$, or IL-10 was detected

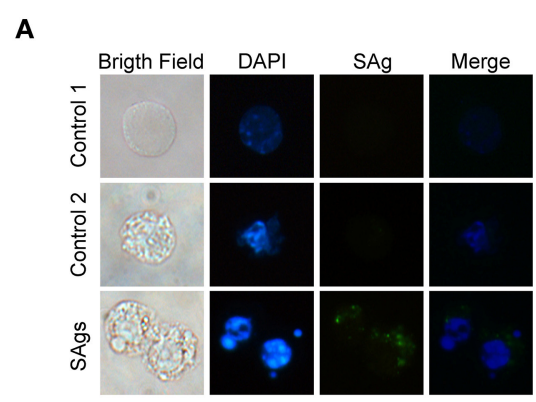

B

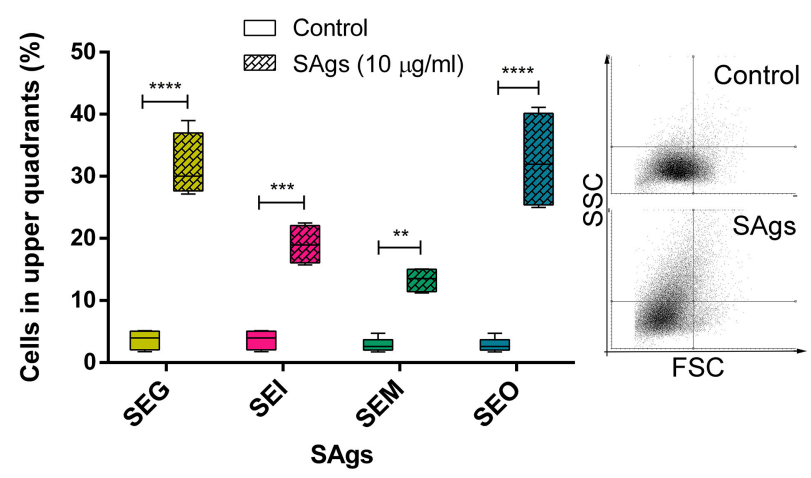

C
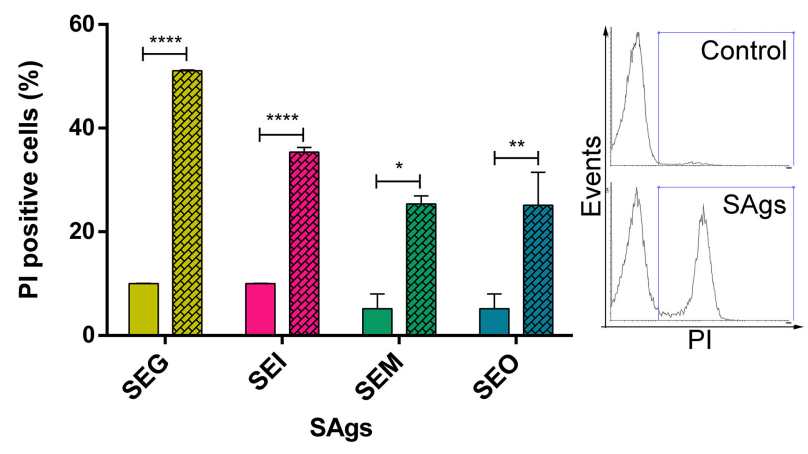

FIGURE 3 | SAgs of the egc operon induced monocytic cell death. (A) After $48 \mathrm{~h}$ of incubation with SAgs, THP-1 cells were labeled with fluorescent antibodies and observed under the microscope; DNA is shown in blue and SAgs in green. In the first column, images in bright field are shown. The upper panel shows the control condition with untreated cells. In the middle and lower panels, monocytes treated with SAgs are shown. In the middle panel, control 2 , cells were incubated with a normal mouse serum and then stained with fluorescent antibodies. In all cases, representative images are shown. (B) Cellular complexity was determined as an increment of cells in the upper quadrants of FSC vs. SCC dot plot. THP-1 cell complexity was assessed by flow cytometry after $48 \mathrm{~h}$ of incubation with SAgs. For this purpose, THP-1 cells were gated for singlets, and then the monocytic population was evaluated by FSC and SCC. Values are expressed as percentage of cells in the upper quadrants. Representative dot plots are shown on the right. (C) THP-1 cells were incubated with SAgs for $48 \mathrm{~h}$ and then stained with FDA/PI. In this case, after singlet cell and monocytic population selection, the percentage of $\mathrm{Pl}^{+}$cells was measured for every SAg treatment and its basal. Values are expressed as the percentage of $\mathrm{Pl}^{+}$cells. Representative histograms are shown on the right. Data are expressed as the mean \pm SEM of at least three independent experiments. Asterisks represent statistical significance with respect to untreated cells: ${ }^{\star} p<0.05,{ }^{* \star} p<0.01,{ }^{\star \star \star} p<0.001,{ }^{\star \star \star \star} p<0.0001$ 

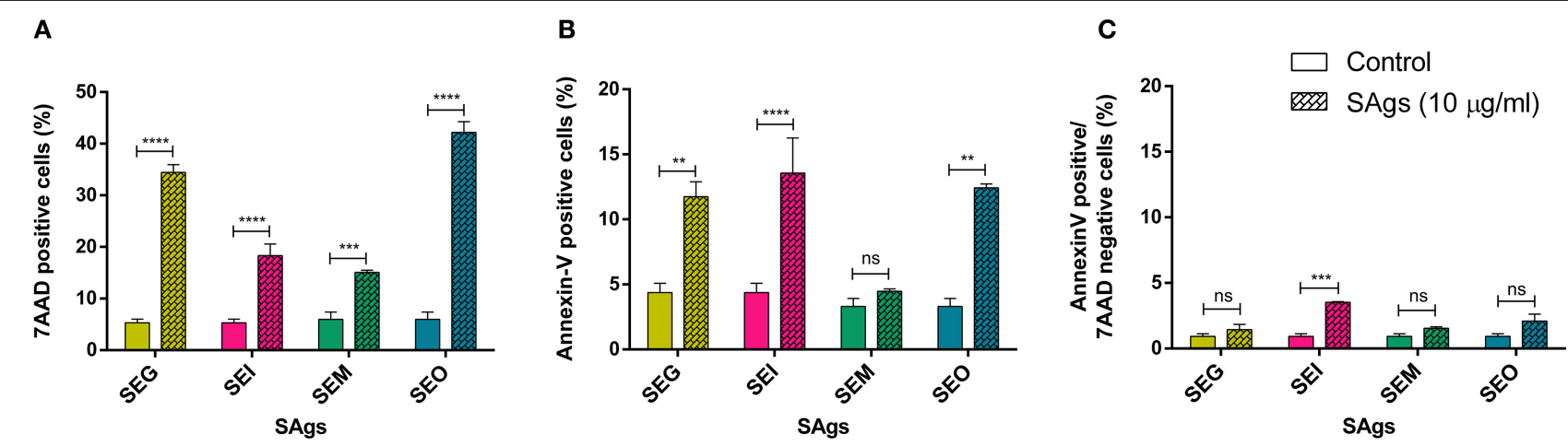

FIGURE 4 | SAgs induced cell death in THP-1 cells by different mechanisms. After $48 \mathrm{~h}$ of incubation with SAgs, THP-1 cells were incubated with Annexin V-PE and 7AAD, and the proportion of positive cells was measured before the singlet and monocytic population gating strategy. Values are expressed as the percentages of 7AAD positive cells (A), Annexin V positive cells (B), and Annexin V-positive/7AAD-negative cells (C). Data are expressed as the mean \pm SEM of at least three independent experiments. Asterisks represent statistical significance with respect to untreated cells: ${ }^{* *} p<0.01,{ }^{\star * \star} p<0.001,{ }^{\star \star \star \star} p<0.0001$, ns, non-significant difference.

(results not shown). Evidently, there is cell activation at the same time that death process starts to occur.

Interestingly, SEG was the weakest to induce IL-6 production by THP- 1 cells and in all cases showed a decline in cytokine levels at the highest concentrations (Figure 6).

\section{SAgs Induce Cell Death in Monocytes Differentiated Into Macrophages}

Since macrophages are the major phagocytic cells, THP-1 cells were differentiated into them by treatment with PMA and then incubated with SAgs to evaluate their effects.

To evaluate cell death, $\mathrm{AO} / \mathrm{EtBr}$ assay was performed (Figures 7A,B). THP-1 cells treated with PMA and incubated with SAgs for $48 \mathrm{~h}$ followed by $\mathrm{AO} / \mathrm{EtBr}$ staining showed a reduction on the macrophage-like cell viability. Although the effect on viability is less marked than with THP-1 cells, all SAgs augmented the percentage of death by apoptosis, with SEG being the one that induced the lowest increment. In contrast, even though all SAgs showed an increase in the percentage of cells undergoing necrosis, that increment was significantly higher than the control for SEG, SEM, and SEO, but not for SEI.

All SAgs of the egc operon induced macrophage production of IL-6 in a concentration-dependent manner, but SEG and SEI increased the production of this cytokine at lower doses than SEM and SEO (Figure 7C). Production of IL-12, IFN- $\gamma$, or IL-10 was not detected in any case (results not shown).

\section{Monocyte Damage Is Mediated by SAgs Interaction With DR1 HLA Class II Molecules}

With the aim of verifying whether the SAg effect on monocytes could be extended to streptococcal superantigen A (SSA), we pre-incubated THP-1 cells with SSA and found 60\% inhibition of cell proliferation, similar to that obtained with staphylococcal SAgs (Figure 8). SSA inhibition of proliferation, as well as SEG and SEI inhibition, was abrogated by incubation with
$\mathrm{F}(\mathrm{ab})_{2} 2$ portion of specific polyclonal antibodies for each SAg (Figure 8).

Since the interaction of SEG and SEI with DR1-HLA, an isoform of the HLA class II molecule expressed on the THP1 cell surface, is well-documented $(35,45,65)$, we analyzed if SAgs damage to monocytic cells could be attributed to the binding of DR1. In addition, we also analyzed if the SAg SSA from S. pyogenes displayed a similar effect on monocytic cells. We had previously observed that SSA caused inhibition of proliferation similar to the SAgs of the egc operon (results not shown). SAgs and recombinant DR1 were pre-incubated at equimolar concentration for $60 \mathrm{~min}$ at $37^{\circ} \mathrm{C}$, and the effects of the complex on THP-1 cells were analyzed by proliferation assay. The results in Figure 8 show that the pre-incubation of SAgs with the DR1 molecule inhibits the SAg effects on monocytes when proliferation is measured. These results strongly suggest that the SAg binding site with DR1 is required for THP-1 cell damage mediated by these toxins.

\section{SAgs Induce the Upregulation of Different Cluster Differentiation Markers Through Molecules Other Than DR1}

All evaluated SAgs at $1 \mu \mathrm{g} / \mathrm{ml}$ had the capacity to induce the increase of CD14, CD40, and CD86 markers on THP-1 cells. CD14-positive cells were increased between 5 and 15\% by SAgs with respect to control (untreated cells) (Figure 9A). CD14 ultimately activates NF- $\mathrm{B}$, and its overexpression shows a more mature stage of monocytes, which are shown slightly activated here.

CD40 signaling plays an important role in the proliferation and differentiation of $\mathrm{B}$ cells, and its upregulation implies monocytic activation. An increment of at least 100\% of CD40positive monocytes was observed after incubation with SAgs, with respect to control (Figure 9C).

In concordance, the co-stimulatory molecule CD86 is upregulated up to $50 \%$ by SAg incubation (Figure 9E). CD86 induces lymphocyte activation, thereby triggering cellular 


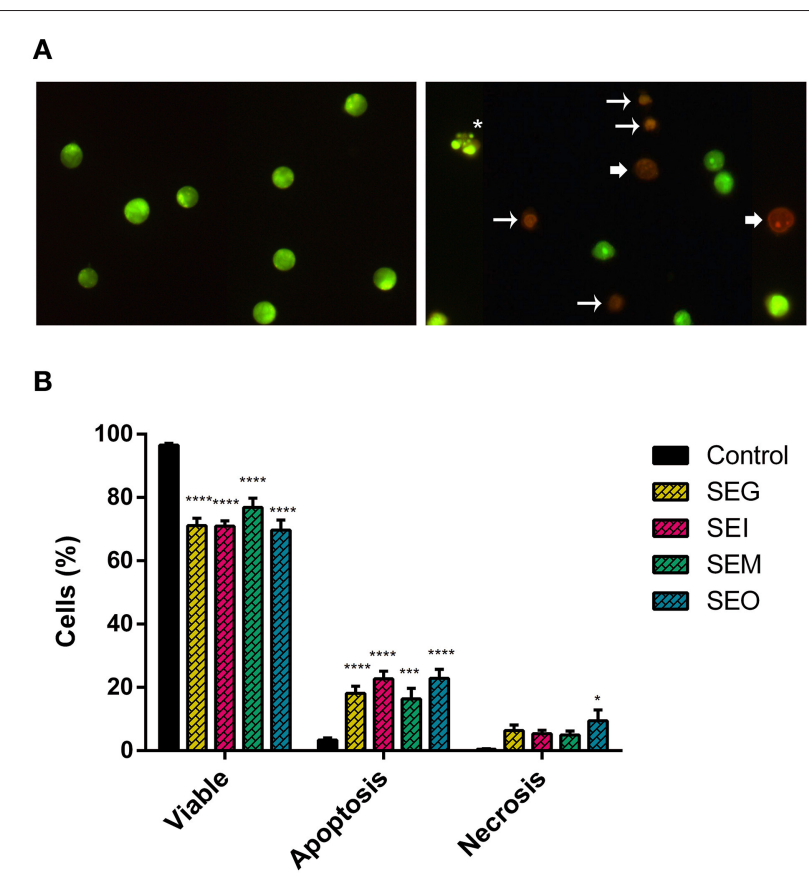

C

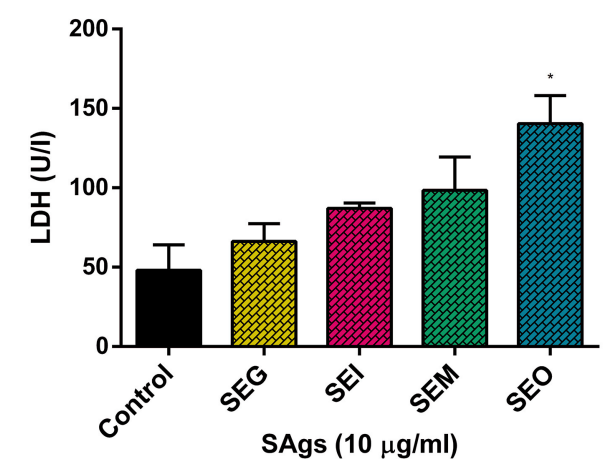

FIGURE 5 | SAgs induced cell death in THP-1 cells by apoptosis and some necrosis. Acridine orange-ethidium bromide staining of monocytic cells (THP-1) under different treatment conditions (representative images). (A) Control THP-1 cells (left panel) and SAgs treatment (right panel) are shown. Asterisks indicate early apoptosis cells, regular arrows show late apoptosis cells, and wide arrows show necrosis. (B) Viability and type of death percentage of THP-1 cells treated with SAgs or untreated (control). The result is based on the analysis of live and apoptotic/necrotic cells following acridine orange-ethidium bromide (AO/EtBr) staining. (C) Analysis of $\mathrm{LDH}$ assay of THP-1 cells treated with SAgs or left untreated. ${ }^{*} p<0.05,{ }^{* \star *} p<0.001,{ }^{* \star \star \star} p<0.0001$.

immune response, although it has also been implicated in immune regulation.

The upregulation of CD14 and CD40 did not disappear when SAgs were pre-incubated with DR1 before incubation with THP1 cells (Figures 9B,D), suggesting that there are other possible molecular targets for SAgs on the surface of monocytes, which trigger the augmented expression of these molecules. For CD86, the upregulation caused by SAgs is partially prevented when preincubated with DR1 (Figure 9F), also indicating more than one target implicated in this molecule regulation.

\section{Phagocytosis Is Not Induced by Incubation With SAgs}

When pre-incubated with SEG, SEI, or SSA, THP-1 cells did not change the ratio of phagocytosis of heat-killed bacteria (SP Figure 2). This result shows that, although an activated profile can be seen, the effector profile of these cells is not well-developed, as could be suggested by previous results.

\section{Gp130, a Glycoprotein Expressed on the Monocytic Cells, Binds Non-classical SAgs}

The molecule gp130, a glycoprotein expressed on monocyte cell surface (73), as described as a possible target of classical SAgs having an Asp227, a residue which is also involved in the binding to the $\beta$ chain of the DR1 (48). Considering that SEI, a non-classical SAg, possesses an Asp in the homologous position (Asp209) (45), we analyzed SEI interaction with gp130 by SPR. One-fold dilutions of SEI $(40-2.5 \mu \mathrm{M})$ were passed through gp130 immobilized on a CM5 chip surface displaying a specific interaction (Figure 10). The kinetic 1:1 interaction model displayed unambiguous results exhibiting a $K_{\mathrm{D}}$ of 1.7 $\times 10^{-5} \mathrm{M}$, with a very slow association rate $\left(k_{\text {on }}\right)$ of $(8.3 \pm$ $0.2) \times 10^{2}(\mathrm{Ms})^{-1}$ and a moderate dissociation rate $\left(k_{\mathrm{off}}\right)$ of $(13.8 \pm 0.3) \times 10^{-3} \mathrm{~s}^{-1}$. Even though the calculations of the rates were univocal, the model did not display a good fit to the experimental values. When a second model, assuming a cooperative model or a 1:2 interaction was applied, a similar value of $K_{\mathrm{D}}$ was obtained. Considering that the interaction between DR1 and SEI is mediated by $\mathrm{Zn}$, we also performed SPR in the presence of EDTA to sequester the cation (45), and the binding was not avoided (data not shown), suggesting that the SEI-gp130 interaction is independent of $\mathrm{Zn}$.

Since the interaction between gp130 and SAg was only described for SEA and it was suggested that this interaction would depend on the presence of Asp227, we analyzed if the egc SAg SEG, which lacks Asp227 and binds to the DR1 $\alpha$ chain (35), also interacts with gp130. Surprisingly, SEG showed a higher affinity for gp130 than SEI, displaying a faster $k_{\text {on }}$ and a slower $k_{\text {off }}$ than SEI (Table 2, Figure 10). SEM and SEO also displayed a specific interaction with gp130 (Figure 10) with $K_{\mathrm{D}}$ values similar to that calculated for the SEG-gp130 interaction. The affinity between SEG, SEM, or SEO with gp130 did not show significant differences (Table 2).

\section{DISCUSSION}

In the current study, we determined that the egc operon is frequently found in the 13 analyzed strains, in concordance with an extensive prospective study in Colombia (74). In contrast to this study, our results in the analyzed strains demonstrated that sen (previously sek) was more frequent than the operon itself. All the analyzed strains carrying the egc operon are also bearers of seu, increasing the virulence of the $S$. aureus strains $(18,49)$. This phenomenon could be explained in terms of the increment of $\mathrm{v} \beta$ TCR isoforms interacting with different SAgs, which allows a major activation of the $\mathrm{T}$ cell population. Former publications described seven types of egc operon. Here we found a new form 

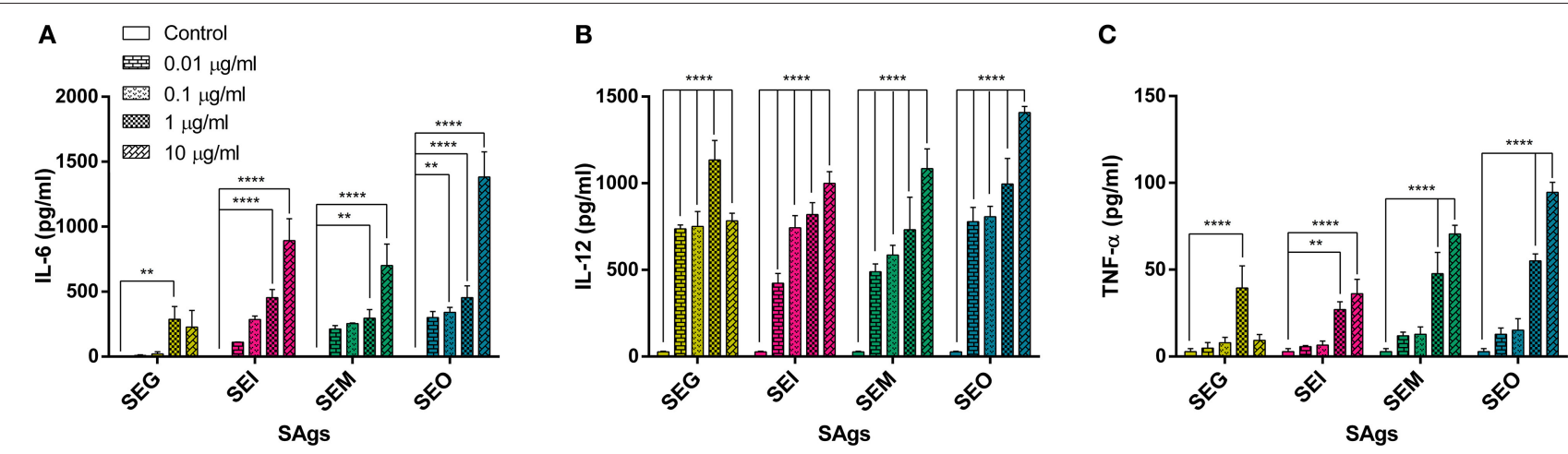

FIGURE 6 | All SAgs induced production of pro-inflammatory cytokines by THP-1 cells. Cytokines were measured in supernatants of treated cells; values are expressed in pg/ml. IL-6 (A), IL-12 (B), and TNF- $\alpha$ (C) production is shown. No production of IL-10, IL-17, or IFN- $\gamma$ was detected in any case. Data are expressed as the mean \pm SEM of at least three independent experiments. Asterisks represent statistical significance with respect to untreated cells: ${ }^{\star \star} p<0.01,{ }^{\star \star \star \star} p<0.0001$.

of the operon, named egc 8 , which is characterized by the absence of the seo gene.

Although sed and sej can be encoded in the same plasmid (71), we found them separately in the genomic DNA of two different strains. These results are not surprising as many types of sags are encoded in mobile genomic elements which allow the integration into chromosomal DNA.

In general, staphylococcal sag genes are well-conserved and display minor allelic variations. However, we have previously described new allelic variants between seg and sei genes in Argentinean autochthonous strains (35). Pediatric isolates revealed mutations that were expressed as up to 10 changes in the SEI amino acid sequence and two in the SEG amino acid sequence. In this study, we observed that adult isolates displayed lower variability in the DNA sequence which resulted in non-variations detected for the sei nucleotide sequences compared with the consensus and four mutations distributed in pairs in SEG predictive mature proteins. These results could suggest that sag genes obtained from strains infecting adults and ambulatory patients displayed much lower variability than strains isolated from pediatric patients. The mutations detected in the SEG predictive mature protein altered residues located outside the MHC-II binding site or the TCR contact surface. These mutations appear as residues highly exposed to the solvent, located in mobile loops in the quaternary structure of the protein and very accessible to antibody recognition, suggesting a target to avoid the neutralization in future infections $(9,35,75)$.

The SAg effects on T cells are very well-documented; however, the actions of these toxins on cells of the innate immunity at the early stages of infection when $\mathrm{T}$ cells are absent have not been deeply evaluated. Previously, our group described the interaction between SEG and mouse dendritic cells (mDCs) (59) using an in vivo and in vitro model. SAgs activate $\mathrm{mDCs}$, increasing the phagocytosis process and inhibiting its maturation. In addition, we demonstrated that SAgs enter in the DC, avoiding the classical pathway of antigen degradation, and are finally exposed as intact molecules on the DC surface, a situation that would allow the interaction with MHC-II and TCR when the DCs encounter the $\mathrm{T}$ cells in the lymph nodes (59). However, as far as we know, SAgs impact on other isolated innate immune cells, such as human monocytes and macrophages, had not been studied yet.

Considering that the egc operon is the most frequent SAg cluster detected in autochthonous strains of $S$. aureus, we evaluated the activity of its SAgs over monocytes and macrophages using the THP-1 cell line as a model of human monocytes. A previous work reported that the interaction between human monocytes enriched from PBMCs and the staphylococcal enterotoxin B (SEB) induced monocyte apoptosis and secretion of IFN- $\gamma$ (56). However, the presence of T cells, source of IFN- $\gamma$ (76), in those preparations cannot be discarded. In the present work, SEG, SEI, SEM, and SEO inhibit monocyte basal proliferation in a dose-dependent manner, promoting cell death mostly by an apoptotic process with less incidence of necrotic death, exhibiting a proinflammatory profile of cytokines characterized by high levels of TNF- $\alpha$, IL-6, and IL-12, but no IFN- $\gamma$. Only SEI induced early apoptosis, suggesting some differences among SAgs kinetic behavior at cell death level. The absence of CD4+ T cells in the culture could explain the lack of IFN- $\gamma$ production in THP-1 cells. The secretion of this cytokine and the mechanism of cell death in monocytes seem to depend, in part, on the presence of $\mathrm{CD}^{+} \mathrm{T}$ cells (76). The released cytokines are in agreement with an M1 profile, with a high inflammatory environment that could promote a Th1 response that it is not the most appropriate for the $S$. aureus eradication. In concordance with these results, no IL10 was detected, favoring a proinflammatory cytokine storm which is essential for TSS unleashing. It was reported that THP-1 monocyte cells could secrete IL-17A under certain stimuli (77). Nevertheless, not one of the egc SAgs induced IL-17A secretion under our experimental conditions.

Monocytic- and macrophagic-like cells showed the same profile of proliferation inhibition and production of proinflammatory cytokines, but only the macrophagic-like cells treated with SEM and SEO had the capacity to induce the production of nitrites at higher concentrations $(100 \mu \mathrm{g} / \mathrm{ml}$, 


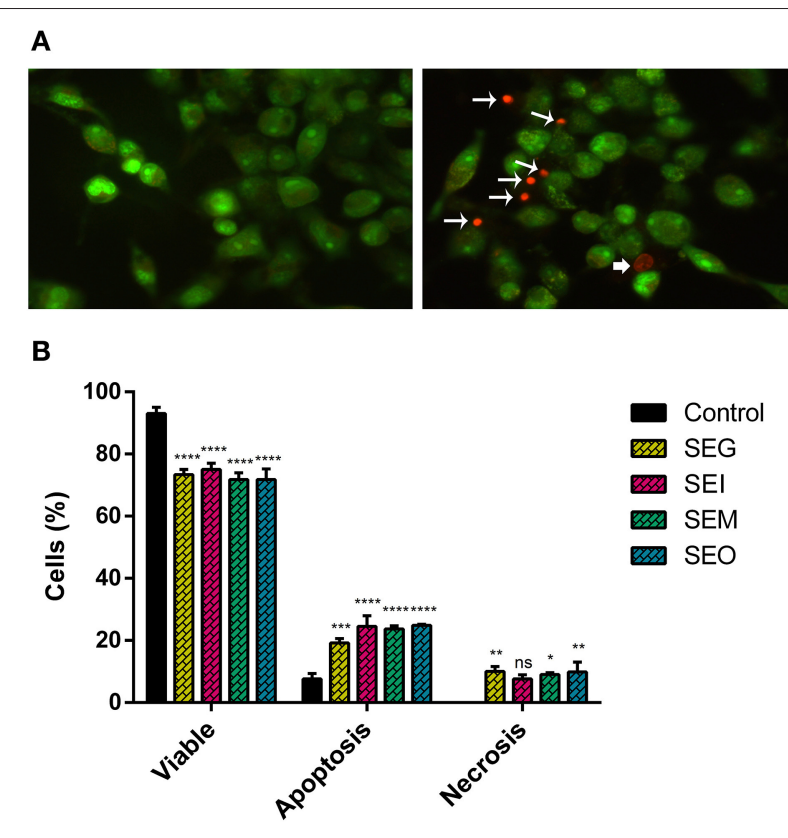

C

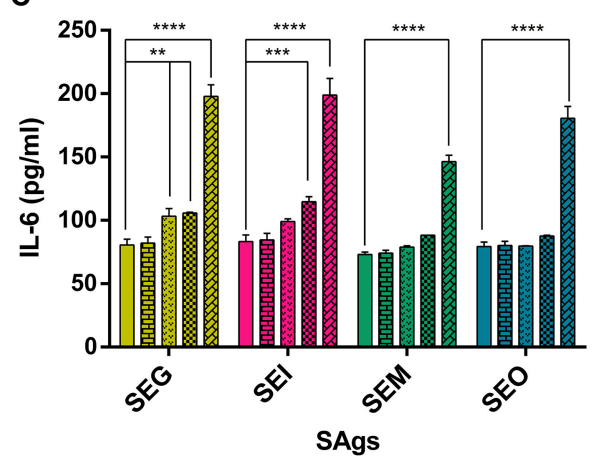

FIGURE 7 | PMA THP-1 differentiated cells are more sensitive than THP-1 cells to the SAg effect. Acridine orange-ethidium bromide staining of PMA-treated THP-1 cells under different treatment conditions (representative images). (A) Control THP-1/PMA cells (left panel) and SAgs treatment (right panel) are shown. Asterisks indicate early apoptosis cells, regular arrows show late apoptosis cells, and wide arrows show necrosis. (B) Viability and type of death percentage of THP-1/PMA cells treated with SAgs or untreated (control). The result is based on the analysis of live and apoptotic/necrotic cells following acridine orange-ethidium bromide ( $\mathrm{AO} / \mathrm{EtBr}$ ) staining. (C) Cytokines were measured in supernatants by ELISA; production of IL-6 is shown. Values are expressed in $\mathrm{pg} / \mathrm{ml}$. Data are expressed as the mean \pm SEM of at least three independent experiments. Asterisks represent statistical significance with respect to untreated cells: ${ }^{*} p<0.05,{ }^{* \star} p<0.01,{ }^{* \star *} p<0.001,{ }^{* \star * *} p<0.0001$.

data not shown), a characteristic of classical macrophage activation, which would accompany the previously mentioned inflammatory response.

In order to determine if the effects observed on monocytes were restricted to the action of egc SAgs or could be extended to enterotoxins of other bacterial species, we also evaluated the effect of streptococcal superantigen A (SSA) on innate immune system cells. Although staphylococcal and streptococcal SAgs display structural and behavioral similarities,

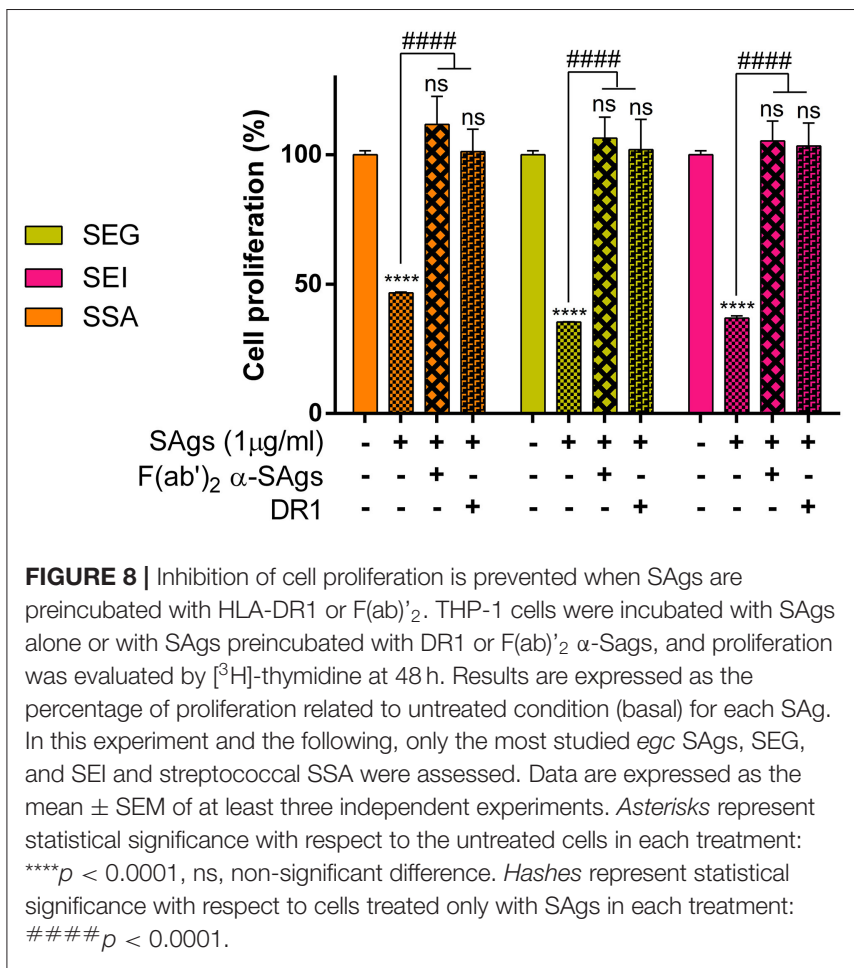

staphylococcal and streptococcal TSS differ in their clinical signs, origin of infection, and prognosis $(66,78)$. In order to elucidate if egc SAgs and SSA shared comparable effects on innate immune system cells, we studied both types of toxins. egc SAgs and SSA inhibited monocytic cell proliferation and induced the same monocyte phenotype: SEG, SEI, and SSA induced the overexpression of cluster differentiation molecules 14, 40, and 86. Despite this fact, no increase in phagocytosis was observed in either case, showing an inefficient activation of monocytic cells by these SAgs. In a previous work, we reported that the treatment of dendritic cells with SEG, in the absence of $\mathrm{T}$ cells, did not disturb the viability of these cells, increased phagocytosis, and inhibited cell maturation (59).

Monocytic THP-1 cells express high levels of MHC-II molecule DR1, a natural ligand of SAgs (79). The interaction of DR1 with SEG, SEI, and SSA is very well documented (35, $45,65,80)$. Consequently, we investigated if the effect of SAgs on monocytes was mediated by the SAg binding site with DR1. Pre-incubation of SAgs with DR1 avoided the effect of SAgs on monocytic cells. These results could be in concordance with those published by Ferreira Duarte et al. (60) where staphylococcal enterotoxin A (SEA) inhibits mouse neutrophil migration, which is reverted prior to incubation of the cells with an antibody to the MHC-II molecule.

The induction of the expression of CD14 and CD40 after SAg treatment seemed to be independent of the interaction site with the DR1, suggesting that other sites of the SAgs or other molecules on the monocyte surface could be involved in 

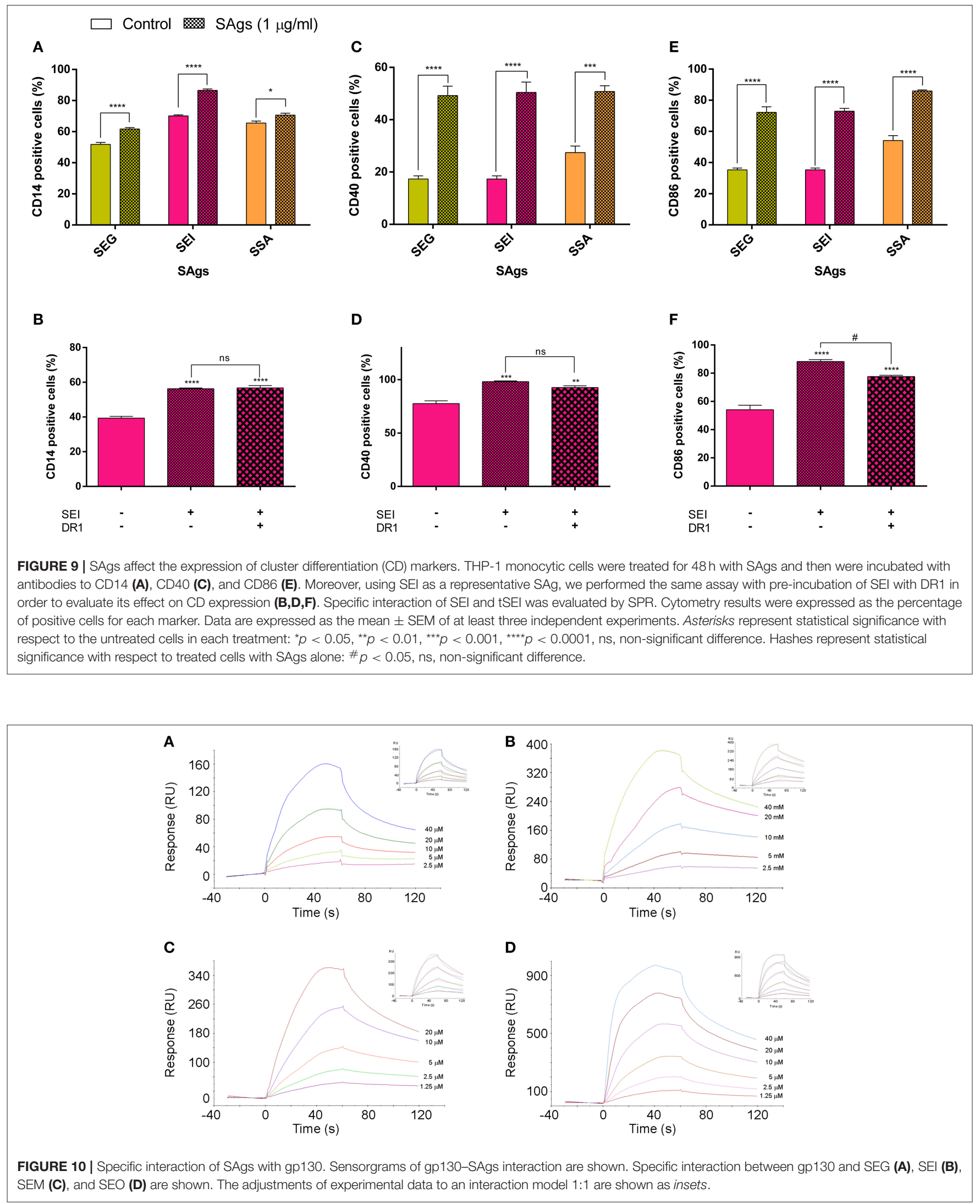
TABLE 2 | SAgs interaction with Gp130 by SPR.

\begin{tabular}{lccc}
\hline & \multicolumn{3}{c}{$\mathbf{g p 1 3 0}$} \\
\cline { 2 - 4 } SAgs & $\boldsymbol{K}_{\text {on }}(\mathbf{M s})^{-1}$ & $\boldsymbol{K}_{\text {off }}(\mathbf{s})^{-1}$ & $\boldsymbol{K}_{\mathbf{D}}(\mathbf{M})$ \\
\hline SEl & $(8.3 \pm 0.2) \times 10^{2}$ & $(13.8 \pm 0.3) \times 10^{-3}$ & $1.7 \times 10^{-5}$ \\
SEG & $(11.9 \pm 0.1) \times 10^{2}$ & $(6.2 \pm 0.1) \times 10^{-3}$ & $5.2 \times 10^{-6}$ \\
SEM & $(19.9 \pm 0.1) \times 10^{2}$ & $(9.9 \pm 0.4) \times 10^{-3}$ & $5.0 \times 10^{-6}$ \\
SEO & $(22.7 \pm 0.6) \times 10^{2}$ & $(12.6 \pm 0.2) \times 10^{-3}$ & $5.6 \times 10^{-6}$ \\
\hline
\end{tabular}

this process. New targets of SAgs on the APC were recently described $(42,81,82)$. The interaction between classical SAgs and CD28, and with B7.2 (CD86), the cognate ligand of the CD28, was already described by others $(40-44,47)$ and could promote a full activation of $\mathrm{T}$ cells. The interaction between SAgs and B7.2 would be carried out through a conserved domain among classical and non-classical SAgs. However, the interactions between these new targets and non-classical SAgs have not been studied yet. In our study, we observed that monocytic-like cells treatment with non-classical SAgs induces an overexpression of CD86, which is partially abrogated when SAgs are pre-incubated with the DR1 molecule (Figure 9E). Since macrophages interact with Th1 cells in the periphery, the overexpression of CD86 could promote a strong activation of the Th1 cells, conducting to the depletion of these cells as happens in the lymph node. CD38 was also postulated by Zilber et al. (82) as another SAg ligand on the monocyte surface and could be considered as a possible candidate to cooperate with DR1 and mediate monocytic activation and subsequent death induced by these toxins. Gregory et al. (81) postulated CD1a as a costimulatory molecule on monocytes, which could contribute to T cell activation by SAgs.

Only one study reported that a classical staphylococcal superantigen, SEA, could bind to gp130, a signal transductor of IL-6, involving the MHC-II interaction site (48). SEA binds to MHC-II with high affinity, compromising the residues which interact with $\mathrm{Zn}$, promoting a long half-life complex with the beta chain of the DR1 molecule. We previously reported that SEI binds to the $\beta$ chain of the DR1-MHC-II molecule and the processed peptide in a $\mathrm{Zn}$-dependent manner (45). Since gp130 is expressed on the THP-1 cell surface (73), we evaluated if SEI, a non-classical egc SAg, interacts with this protein by SPR. Our results demonstrated that SEI specifically binds to gp130 with moderate affinity and by one order of magnitude lower than the value already reported by SEI-DR1 $\left(K_{\mathrm{D}} 10^{-6}\right.$ $\mathrm{M})$. In addition, we observed that the treatment with EDTA, a chelating agent of bivalent cations like $\mathrm{Zn}$, did not abrogate the interaction. We also demonstrated that all egc operon nonclassical SAgs have specific interaction with gp130, showing a similar kinetic behavior (Figure 10). The physiological role of these interactions could be explained considering that SAgs block gp130, preventing IL-6 stimuli and the activation of STAT3 pathway, which is needed for the expression of IL-30 in monocytes (73). Since it has been suggested that IL-30 could be involved in the sepsis-control-modulating cytokines secreted by NKT cells (83), inhibition of the synthesis of IL-30 would suit the spread of bacteria. Nevertheless, more studies must be conducted to determine the biological meaning of this interaction.

Considering that neither SEG and SEI nor SSA showed significant differences when human monocytes were treated with them, we could suggest that this first step of infection, which is essential for bacterial dissemination and the subsequent disease prognosis, does not explain the discrepancy of progression to the TSST observed among toxins belonging to different species (66). Nevertheless, it is clear that TSS involves other components of the pathogens which are not evaluated in the present work.

As general conclusions of this work, we propose that SAgs inhibit monocytic/macrophagic effector cells, promoting a partial immunosuppression state of the host in the first stages of the infection, which would favor bacterial spread. Despite that these toxins increase the expression of the differentiation clusters evaluated, which suggest cell activation, they do not stimulate phagocytosis, and as a consequence the viability of the bacteria would not be affected. Furthermore, the high level of proinflammatory cytokines released due to SAgs stimulation could induce a type I acquired immune response. Even if SAgs promote cell death in a high percentage of the monocytic/macrophagic population, the fraction that still remains alive could be maintained primed with SAgs. As a consequence, when Th1 cells contact the SAg-primed macrophages, they would suffer a process of apoptosis or energy, enhancing the immunosuppressive status of the host.

\section{DATA AVAILABILITY STATEMENT}

The datasets generated for this study can be found in the GenBank MK947360, MK947361, MK947362, MK947363, MK947364, MK947365, MK947366.

\section{ETHICS STATEMENT}

Animal experiments (antisera production) were reviewed and approved by the Laboratory Animal Welfare Committee CICUAL, Facultad de Farmacia y Bioquimica, Universidad de Buenos Aires, Resolution No: 2349-18.

\section{AUTHOR CONTRIBUTIONS}

$\mathrm{SN}, \mathrm{MD}, \mathrm{EM}$, and MMF conceived and designed the experiments and analyzed the data. SN, MD, MS, MA, LI, MJF, and MT performed the experiments. AM and EM contributed with reagents, materials, and analysis tools. $\mathrm{SN}, \mathrm{MD}, \mathrm{EM}$, and $\mathrm{MMF}$ wrote the paper.

\section{FUNDING}

This work was supported by Universidad de Buenos Aires (\#20020130200233BA, 2014-2017, extension, 2018) and Consejo Nacional de Investigaciones Científicas (CONICET; \#114201101003829). 


\section{ACKNOWLEDGMENTS}

We thank Daniela Ureta and Tomás Lombardo (Flow Cytometry Unit, IDEHU) and Carolina Mourelle (Animal Facilities and Care, IDEHU) for all the technical assistance.

\section{REFERENCES}

1. Chesney PJ. Clinical aspects and spectrum of illness of TSS: overview. Cli Infect Dis. (1989) 11:S1-7. doi: 10.1093/clinids/11.Supplement_1.S1

2. Tong SYC, Davis JS, Eichenberger E, Holland TL, Fowler VG. Staphylococcus aureus infections: epidemiology, pathophysiology, clinical manifestations, and management. Clin Microbiol Rev. (2015) 28:603-61. doi: 10.1128/CMR.00134-14

3. Lowy FD. Staphylococcus aureus Infections. New Engl J Med. (1998) 339: 520-32. doi: 10.1056/nejm199808203390806

4. Yew MS, Leong WM. Contemporary management and outcomes of infective tunnelled haemodialysis catheter-related right atrial thrombi: a case series and literature review. Singapore Med J. (2019) 1-15.

5. Fraser JD, Proft T. The bacterial superantigen and superantigen-like proteins. Immunol Rev. (2008) 225:226-43. doi: 10.1111/j.1600-065X.2008. 00681.x

6. Blank C, Luz A, Bendigs S, Erdmann A, Wagner H, Heeg K. Superantigen and endotoxin synergize in the induction of lethal shock. Eur J Immunol. (1997) 27:825-33. doi: 10.1002/eji.1830270405

7. Dalpke AH, Heeg K. Synergistic and antagonistic interactions between LPS and superantigens. J Endotoxin Res. (2003) 9:51-4. doi: 10.1177/09680519030090010601

8. MacIsaac CM, Curtis N, Cade J, Visvanathan K. Superantigens in sepsis. Int Congress Ser. (2006) 1289:121-4. doi: 10.1016/j.ics.2005.11.014

9. Proft T, Fraser JD. Bacterial superantigens. Clin Exp Immunol. (2003) 133:299-306. doi: 10.1046/j.1365-2249.2003.02203.x

10. Chintagumpala MM, Mollick JA, Rich RR. Staphylococcal toxins bind to different sites on HLA-DR. J Immunol. (1991) 147: 3876-81

11. Dellabona P, Peccoud J, Kappler J, Marrack P, Benoist C, Mathis D, et al. Superantigens interact with MHC class II molecules outside of the antigen groove. Cell. (1990) 62:1115-21. doi: 10.1016/0092-8674(90)90388-U

12. Dinges MM, Orwin PM, Schlievert PM. Exotoxins of Staphylococcus aureus. Clin Microbiol Rev. (2000) 13:16-34. doi: 10.1128/CMR.13.1.16

13. Fischer H, Dohlsten M, Lindvall M, Sjogren H-O, Carlsson3 R. Binding of staphylococcal enterotoxin A to HLA-DR on B cell lines. I Immunol. (1989) 142:3151-7.

14. Fraser JD. High-affinity binding of staphylococcal enterotoxins A and B to HLA-DR. Nature. (1989) 339:221-3. doi: 10.1038/339221a0

15. Shupp JW, Jett M, Pontzer CH. Identification of a transcytosis epitope on staphylococcal enterotoxins. Infect Immun. (2002) 70:2178-86. doi: 10.1128/IAI.70.4.2178-2186.2002

16. Racke MK, Bonomo A, Scott DE, Cannella B, Levine A, Raine CS, et al. Cytokine-induced immune deviation as a therapy for inflammatory autoimmune disease. J Exp Med. (1994) 180:1961-6. doi: 10.1084/jem.180.5.1961

17. Conrad B, Weissmahr RN, Böni J, Arcari R, Schüpbach J, Mach B. A human endogenous retroviral superantigen as candidate autoimmune gene in type I diabetes. Cell. (1997) 90:303-13. doi: 10.1016/S0092-8674(00) 80338-4

18. Kuroda M, Ohta T, Uchiyama I, Baba T, Yuzawa H, Kobayashi I, et al. Whole genome sequencing of meticillin-resistant Staphylococcus aureus. Lancet. (2001) 357:1225-40. doi: 10.1016/S0140-6736(00)04403-2

19. Sutkowski N, Conrad B, Thorley-Lawson DA, Huber BT. EpsteinBarr virus transactivates the human endogenous retrovirus HERVK18 that encodes a superantigen. Immunity. (2001) 15:579-89. doi: 10.1016/S1074-7613(01)00210-2

20. Madakamutil LT, Maricic I, Sercarz E, Kumar V. Regulatory T cells control autoimmunity in vivo by inducing apoptotic depletion of

\section{SUPPLEMENTARY MATERIAL}

The Supplementary Material for this article can be found online at: https://www.frontiersin.org/articles/10.3389/fimmu. 2019.03008/full\#supplementary-material

activated pathogenic lymphocytes. J Immunol. (2003) 170:2985-92. doi: 10.4049/jimmunol.170.6.2985

21. Necidová L, Bursová Š, Haruštiaková D, Bogdanovičová K, Lačanin I. Effect of heat treatment on activity of staphylococcal enterotoxins of type A, B, and C in milk. J Dairy Sci. (2019) 102:3924-32. doi: 10.3168/jds.2018-15255

22. Mccormick JK, Yarwood JM, Schlievert PM. Toxic shock syndrome and bacterial superantigens: an update. Annu Rev Microbiol. (2001) 55:77-104. doi: 10.1146/annurev.micro.55.1.77

23. Ono HK, Omoe K, Imanishi K, Iwakabe $\mathrm{Y}, \mathrm{Hu} \mathrm{D}$, Kato $\mathrm{H}$, et al. Identification and characterization of two novel staphylococcal enterotoxins, types $\mathrm{S}$ and $\mathrm{T}$. Infect Immun. (2008) 76:4999-5005. doi: 10.1128/IAI.00045-08

24. Park JY, Fox LK, Seo KS, McGuire MA, Park YH, Rurangirwa FR, et al. Detection of classical and newly described staphylococcal superantigen genes in coagulase-negative staphylococci isolated from bovine intramammary infections. Vet Microbiol. (2010) 147:149-54. doi: 10.1016/j.vetmic.2010.06.021

25. Thomas DY, Jarraud S, Lemercier B, Cozon G, Echasserieau K, Etienne J, et al. Staphylococcal enterotoxin-like toxins U2 and V, two new staphylococcal superantigens arising from recombination within the enterotoxin gene cluster. Infect Immun. (2006) 74:4724-34. doi: 10.1128/IAI.00132-06

26. Abrahmsen L, Dohisten M, Segren S, Bjork P, Jonsson E, Kalland T. Characterization of two distinct MHC class 11 binding sites in the superantigen staphylococcal enterotoxin A. EMBO J. (1995) 14:2978-86. doi: 10.1002/j.1460-2075.1995.tb07300.x

27. Leder L, Llera A, Lavoie PM, Lebedeva MI, Li H, Sékaly R-P, et al. A mutational analysis of the binding of staphylococcal enterotoxins B and C3 to the T cell receptor $\beta$ chain and major histocompatibility complex class II. J Exp Med. (1998) 187:823-33. doi: 10.1084/jem.187.6.823

28. Leslie DS, Vincent MS, Spada FM, Das H, Sugita M, Morita CT, et al. CD1mediated gamma/delta T cell maturation of dendritic cells. J Exp Med. (2002) 196:1575-84. doi: 10.1084/jem.20021515

29. Li H, Llera A, Malchiodi EL, Mariuzza RA. The structural basis of $\mathrm{T}$ cell activation by superantigens. Annu Rev Immunol. (1999) 17:435-66. doi: 10.1146/annurev.immunol.17.1.435

30. Li Y, Li H, Dimasi N, McCormick JK, Martin R, Schuck P, et al. Crystal structure of a superantigen bound to the high-affinity, zincdependent site on MHC class II. Immunity. (2001) 14:93-104. doi: 10.1016/S1074-7613(01)00092-9

31. Malchiodi EL, Eisenstein E, Fields BA, Ohlendorf DH, Schlievert PM, Karjalainen $\mathrm{K}$, et al. Superantigen binding to a $\mathrm{T}$ cell receptor $\mathrm{B}$ chain of known three-dimensional structure. J Exp Med. (1995) 182:1833-45. doi: $10.1084 /$ jem.182.6.1833

32. Petersson K, Thunnissen M, Forsberg G, Walse B. Crystal structure of a SEA variant in complex with MHC class II reveals the ability of SEA to crosslink MHC molecules. Structure. (2002) 10:1619-26. doi: 10.1016/S0969-2126(02)00895-X

33. Sundberg EJ, Li Y, Mariuzza RA. So many ways of getting in the way: diversity in the molecular architecture of superantigen-dependent T-cell signaling complexes. Curr Opin Immunol. (2002) 14:36-44. doi: 10.1016/S0952-7915(01)00296-5

34. Petersson K, Håkansson M, Nilsson H, Forsberg G, Svensson LA, Liljas A, et al. Crystal structure of a superantigen bound to MHC class II displays zinc and peptide dependence. EMBO J. (2001) 20:3306-12. doi: 10.1093/emboj/20.13.3306

35. Fernández MM, Guan R, Swaminathan CP, Malchiodi EL, Mariuzza RA. Crystal structure of staphylococcal enterotoxin I (SEI) in complex with a human major histocompatibility complex class II molecule. J Biol Chem. (2006) 281:25356-64. doi: 10.1074/jbc.M603969200 
36. Fernández MM, Bhattacharya S, De Marzi MC, Brown PH, Kerzic M, Schuck $\mathrm{P}$, et al. Superantigen natural affinity maturation revealed by the crystal structure of staphylococcal enterotoxin $\mathrm{G}$ and its binding to T-cell receptor Vb8.2. Proteins. (2007) 68:389-402. doi: 10.1002/prot.21388

37. Saline M, Rödström KE, Fischer G, Orekhov VY, Karlsson BG, LindkvistPetersson K. The structure of superantigen complexed with TCR and MHC reveals novel insights into superantigenic T cell activation. Nat Commun. (2010) 1:119. doi: 10.1038/ncomms1117

38. Fernández MM, Cho S, De Marzi MC, Kerzic MC, Robinson H, Mariuzza RA, et al. Crystal structure of staphylococcal enterotoxin G (SEG) in complex with a mouse T-cell receptor $\beta$ chain. J Biol Chem. (2011) 286:1189-95. doi: $10.1074 /$ jbc.M110.142471

39. Hakansson M, Petersson K, Nilsson H, Forsberg G, Bjork P, Antonsson P, et al. The crystal structure of staphylococcal enterotoxin H: implications for binding properties to MHC class II and TcR molecules. J Mol Biol. (2000) 302:527-37. doi: 10.1006/jmbi.2000.4093

40. Arad G, Levy R, Nasie I, Hillman D, Rotfogel Z, Barash U, et al. Binding of superantigen toxins into the CD28 homodimer interface is essential for induction of cytokine genes that mediate lethal shock. PLoS Biol. (2011) 9:e1001149. doi: 10.1371/journal.pbio.1001149

41. Kaempfer R, Arad G, Levy R, Hillman D, Nasie I, Rotfogel Z. CD28: direct and critical receptor for superantigen toxins. Toxins. (2013) 5:1531-42. doi: $10.3390 /$ toxins 5091531

42. Levy R, Rotfogel Z, Hillman D, Popugailo A, Arad G, Supper E, et al. Superantigens hyperinduce inflammatory cytokines by enhancing the B72/CD28 costimulatory receptor interaction. Proc Natl Acad Sci USA. (2016) 113:E6437-46. doi: 10.1073/pnas.1603321113

43. Popugailo A, Rotfogel Z, Supper E, Hillman D, Kaempfer R. Staphylococcal and streptococcal superantigens trigger B7/CD28 costimulatory receptor engagement to hyperinduce inflammatory cytokines. Front Immunol. (2019) 10:942. doi: 10.3389/fimmu.2019.00942

44. Ramachandran G, Tulapurkar ME, Harris KM, Arad G, Shirvan A, Shemesh $\mathrm{R}$, et al. A peptide antagonist of $\mathrm{CD} 28$ signaling attenuates toxic shock and necrotizing soft-tissue infection induced by Streptococcus pyogenes. J Infect Dis. (2013) 207:1869-77. doi: 10.1093/infdis/ jit104

45. Fernández MM, De Marzi MC, Berguer P, Burzyn D, Langley RJ, Piazzon I, et al. Binding of natural variants of staphylococcal superantigens SEG and SEI to TCR and MHC class II molecule. Mol Immunol. (2006) 43:927-38. doi: 10.1016/j.molimm.2005.06.029

46. Unnikrishnan M, Altmann DM, Proft T, Wahid F, Cohen J, Fraser JD, et al. The bacterial superantigen streptococcal mitogenic exotoxin $\mathrm{Z}$ is the major immunoactive agent of Streptococcus pyogenes. J Immunol. (2002) 169:2561-9. doi: 10.4049/jimmunol.169.5.2561

47. Kaempfer R, Popugailo A, Levy R, Arad G, Hillman D, Rotfogel Z. Bacterial superantigen toxins induce a lethal cytokine storm by enhancing B7-2/CD28 costimulatory receptor engagement, a critical immune checkpoint. Receptors Clin Investig. (2017) 4:e1500.

48. Banke E, Rödström K, Ekelund M, Dalla-Riva J, Lagerstedt JO, Nilsson S, et al. Superantigen activates the gp130 receptor on adipocytes resulting in altered adipocyte metabolism. Metab Clin Exp. (2014) 63:831-40. doi: 10.1016/j.metabol.2014.03.004

49. Blaiotta G, Fusco V, von Eiff C, Villani F, Becker K. Biotyping of enterotoxigenic Staphylococcus aureus by enterotoxin gene cluster (egc) polymorphism and spa typing analyses. Appl Environ Microbiol. (2006) 72:6117-23. doi: 10.1128/AEM.00773-06

50. Becker K, Friedrich AW, Lubritz G, Weilert M, Peters G, Von Eiff C. Prevalence of genes encoding pyrogenic toxin superantigens and exfoliative toxins among strains of Staphylococcus aureus isolated from blood and nasal specimens. J Clin Microbiol. (2003) 41:1434-9. doi: 10.1128/JCM.41.4.1434-1439.2003

51. Holtfreter S, Bauer K, Thomas D, Feig C, Lorenz V, Roschack K, et al. egc-encoded superantigens from Staphylococcus aureus are neutralized by human sera much less efficiently than are classical staphylococcal enterotoxins or toxic shock syndrome toxin. Infect Immun. (2004) 72:406171. doi: 10.1128/IAI.72.7.4061-4071.2004

52. Holtfreter S, Grumann D, Schmudde M, Nguyen HTT, Eichler P, Strommenger $\mathrm{B}$, et al. Clonal distribution of superantigen genes in clinical Staphylococcus aureus isolates. J Clin Microbiol. (2007) 45:2669-80. doi: 10.1128/JCM.00204-07

53. Omoe K, Hu DL, Takahashi-Omoe H, Nakane A, Shinagawa K. Comprehensive analysis of classical and newly described staphylococcal superantigenic toxin genes in Staphylococcus aureus isolates. FEMS Microbiol Lett. (2005) 246:191-8. doi: 10.1016/j.femsle.2005.04.007

54. Jarraud S, Peyrat M, Lim A, Tristan A, Bes M, Mougel C, et al. egc, a highly prevalent operon of enterotoxin gene, forms a putative nursery of superantigens in Staphylococcus aureus. J Immunol. (2001) 166:669-77. doi: 10.4049/jimmunol.166.1.669

55. Jarraud S, Mougel C, Thioulouse J, Lina G, Ne Meugnier H, Forey F, et al. Relationships between Staphylococcus aureus genetic background, virulence factors, agr groups (alleles), and human disease. Infect Immun. (2002) 70:63141. doi: 10.1128/IAI.70.2.631-641.2002

56. Takahashi M, Takahashi M, Shinohara F, Takada H, Rikiishi H. Effects of superantigen and lipopolysaccharide on induction of CD80 through apoptosis of human monocytes. Infect Immun. (2001) 69:3652-7. doi: 10.1128/IAI.69.6.3652-3657.2001

57. Nobile C, Lind M, Miro F, Chemin K, Tourret M, Occhipinti G, et al. Cognate $\mathrm{CD} 4+$ T-cell-dendritic cell interactions induce migration of immature dendritic cells through dissolution of their podosomes. Blood. (2008) 111:3579-90. doi: 10.1182/blood-2007-08-107755

58. Dickgreber N, Stoitzner P, Bai Y, Price KM, Farrand KJ, Manning K, et al. Targeting antigen to MHC class II molecules promotes efficient crosspresentation and enhances immunotherapy. J Immunol. (2009) 182:1260-9. doi: $10.4049 /$ jimmunol.182.3.1260

59. Ganem MB, De Marzi MC, Fernández-Lynch MJ, Jancic C, Vermeulen M, Geffner $J$, et al. Uptake and intracellular trafficking of superantigens in dendritic cells. PLoS ONE. (2013) 8:e66244. doi: 10.1371/journal.pone.0066244

60. Ferreira-Duarte AP, Pinheiro-Torres AS, Anhê GF, Condino-Neto A, Antunes E. MHC class II activation and interferon- $\gamma$ mediate the inhibition of neutrophils and eosinophils by staphylococcal enterotoxin type A (SEA). Front Cell Infect Microbiol. (2017) 7:518. doi: 10.3389/fcimb.2017.00518

61. Calabrese EJ, Agathokleous E, Kapoor R, Kozumbo WJ, Rattan SI. Reanalysis of herbal extract data reveals that inflammatory processes are mediated by hormetic mechanisms. Chem Biol Interact. (2019) 314:108844. doi: 10.1016/j.cbi.2019.108844

62. Chanput W, Mes JJ, Wichers HJ. THP-1 Cell line: an in vitro cell model for immune modulation approach. Int Immunopharmacol. (2014) 23:37-45. doi: 10.1016/j.intimp.2014.08.002

63. Dowds TA, Masumoto J, Zhu L, Inohara N, Núñez G. Cryopyrin-induced interleukin $1 \beta$ secretion in monocytic cells: enhanced activity of diseaseassociated mutants and requirement for ASC. J Biol Chem. (2004) 279:219248. doi: 10.1074/jbc.M401178200

64. Munson SH, Tremaine MT, Betley MJ, Welch RA. Identification and characterization of staphylococcal enterotoxin types G and I from Staphylococcus aureus identification and characterization of staphylococcal enterotoxin types G and I from Staphylococcus aureus. Infect Immun. (1998) 66:3337-48.

65. De Marzi MC, Fernández MM, Sundberg EJ, Molinero L, Zwirner NW, Llera AS, et al. Cloning, expression and interaction of human T-cell receptors with the bacterial superantigen SSA. Eur J Biochem. (2004) 271:4075-83. doi: $10.1111 / j .1432-1033.2004 .04345 . x$

66. Javouhey E, Bolze P-A, Jamen C, Lina G, Badiou C, Poyart C, et al. Similarities and differences between staphylococcal and streptococcal toxic shock syndromes in children: results from a 30-case cohort. Front Pediatr. (2018) 6:360. doi: 10.3389/fped.2018.00360

67. Corredor NC, López C, Aguilera PA, Prieto LM, Rodríguez-Leguizamón G, Leal AL, et al. An epidemiological and molecular study regarding the spread of vancomycin-resistant Enterococcus faecium in a teaching hospital in Bogotá, Colombia 2016. BMC Infect Dis. (2019) 19:258. doi: 10.1186/s12879-019-3877-7

68. Robert X, Gouet P. Deciphering key features in protein structures with the new ENDscript server. Nucleic Acids Res. (2014) 42:W320-4. doi: 10.1093/nar/gku316

69. Frayser M, Sato AK, Xu L, Stern LJ. Empty and peptide-loaded class II major histocompatibility complex proteins produced by expression in 
Escherichia coli and folding in vitro. Protein Expr Purif. (1999) 15:105-14. doi: 10.1006/prep.1998.0987

70. Blaiotta G, Ercolini D, Pennacchia C, Fusco V, Casaburi A, Pepe O, et al. PCR detection of staphylococcal enterotoxin genes in Staphylococcus spp. strains isolated from meat and dairy products. Evidence for new variants of seG and seI in S. aureus AB-8802. J Appl Microbiol. (2004) 97:719-30. doi: 10.1111/j.1365-2672.2004.02349.x

71. Omoe K, Ishikawa M, Shimoda Y, Hu D-L, Ueda S, Shinagawa K. Detection of seg, seh, and sei genes in Staphylococcus aureus isolates and determination of the enterotoxin productivities of $S$. aureus isolates harboring seg, seh, or sei genes. J Clin Microbiol. (2002) 40:857-62. doi: 10.1128/JCM.40.3.857-862.2002

72. Sawai H, Domae N. Discrimination between primary necrosis and apoptosis by necrostatin-1 in Annexin V-positive/propidium iodidenegative cells. Biochem Biophys Res Commun. (2011) 411:569-73. doi: 10.1016/j.bbrc.2011.06.186

73. Petes C, Mariani MK, Yang Y, Grandvaux N, Gee K. Interleukin (IL)-6 inhibits IL-27- and IL-30-mediated inflammatory responses in human monocytes. Front Immunol. (2018) 9:256. doi: 10.3389/fimmu.2018. 00256

74. Corredor Arias LF, Luligo Espinal JS, Moncayo Ortiz JI, Santacruz Ibarra JJ, Alvarez Aldana A. Relationship between super antigenicity, antimicrobial resistance and origin of Staphylococcus aureus isolated. Colomb Méd. (2016) 47:15-20. doi: 10.25100/cm.v47i1.1818

75. Proft T, Fraser JD. Streptococcal superantigens: biological properties and potential role in disease. In: Streptococcus pyogenes: Basic Biology to Clinical Manifestations. (2016). Available online at: http://www.ncbi.nlm.nih.gov/ pubmed/26866236

76. Krakauer T. Staphylococcal superantigens: pyrogenic toxins induce toxic shock. Toxins. (2019) 11:178. doi: 10.3390/toxins 11030178

77. Jadhav NJ, Gokhale S, Seervi M, Patil PS, Alagarasu K. Immunomodulatory effect of 1,25 dihydroxy vitamin D3 on the expression of RNA sensing pattern recognition receptor genes and cytokine response in dengue virus infected U937-DC-SIGN cells and THP-1 macrophages. Int Immunopharmacol. (2018) 62:237-43. doi: 10.1016/j.intimp.2018.07.019
78. von Bonin A, Ehrlich S, Malcherek G, Fleischer B. Major histocompatibility complex class II-associated peptides determine the binding of the superantigen toxic shock syndrome toxin-1. Eur J Immunol. (1995) 25:2894-8. doi: 10.1002/eji.1830251028

79. Torres M, Ramachandra L, Rojas RE, Bobadilla K, Thomas J, Canaday DH, et al. Role of phagosomes and major histocompatibility complex class II (MHC-II) compartment in MHC-II antigen processing of Mycobacterium tuberculosis in human macrophages. Infect Immun. (2006) 74:1621-30. doi: 10.1128/IAI.74.3.1621-1630.2006

80. Sundberg EJ, Deng L, Mariuzza RA. TCR recognition of peptide/MHC class II complexes and superantigens. Semin Immunol. (2007) 19:262-71. doi: 10.1016/j.smim.2007.04.006

81. Gregory S, Zilber MT, Charron D, Gelin C. Human CDla molecule expressed on monocytes plays an accessory role in the superantigeninduced activation of T lymphocytes. Hum Immunol. (2000) 61:193-201. doi: 10.1016/S0198-8859(99)00129-9

82. Zilber M-T, Gregory S, Mallone R, Deaglio S, Malavasi F, Charron D, et al. CD38 expressed on human monocytes: a coaccessory molecule in the superantigen-induced proliferation. Proc Natl Acad Sci USA. (2002) 97:28405. doi: 10.1073/pnas.050583197

83. Yan J, Mitra A, Hu J, Cutrera JJ, Xia X, Doetschman T, et al. Interleukin30 (IL27p28) alleviates experimental sepsis by modulating cytokine profile in NKT cells. J Hepatol. (2016) 64:1128-36. doi: 10.1016/j.jhep.2015.12.020

Conflict of Interest: The authors declare that the research was conducted in the absence of any commercial or financial relationships that could be construed as a potential conflict of interest.

Copyright (c) 2020 Noli Truant, De Marzi, Sarratea, Antonoglou, Meo, Iannantuono López, Fernández Lynch, Todone, Malchiodi and Fernández. This is an open-access article distributed under the terms of the Creative Commons Attribution License (CC $B Y)$. The use, distribution or reproduction in other forums is permitted, provided the original author(s) and the copyright owner(s) are credited and that the original publication in this journal is cited, in accordance with accepted academic practice. No use, distribution or reproduction is permitted which does not comply with these terms. 